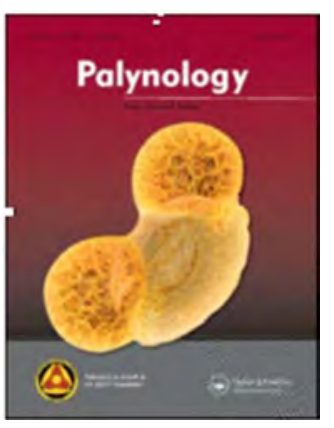

\title{
How palynology could have been paepalology: the naming of a discipline
}

\begin{tabular}{|r|l|}
\hline Journal: & Palynology \\
\hline Manuscript ID & TPAL-2017-0073.R1 \\
\hline Manuscript Type: & Original Article \\
\hline Date Submitted by the Author: & n/a \\
\hline Complete List of Authors: & $\begin{array}{l}\text { Edwards, Kevin; University of Aberdeen, Geography and Environment, } \\
\text { School of Geosciences } \\
\text { Pardoe, Heather S.; Amguedffa Cymru, Natural Sciences }\end{array}$ \\
\hline Keywords: & $\begin{array}{l}\text { Palynology, etymology, E.V. Antevs, H.A. Hyde, D.A. Williams, L.J.D. } \\
\text { Richardson, G. Erdtman }\end{array}$ \\
\hline \multicolumn{2}{|c}{} \\
\hline
\end{tabular}


1 How palynology could have been paepalology: the naming of a

\section{2 discipline}

3

$4 \quad$ Kevin J. Edwards ${ }^{\mathrm{a}, \mathrm{b}}$ and Heather S. Pardoe ${ }^{\mathrm{c}}$

5

$6 \quad{ }^{\mathrm{a}}$ Departments of Geography \& Environment and Archaeology, School of Geosciences,

7 University of Aberdeen, Elphinstone Road, Aberdeen AB24 3UF, UK; ${ }^{b}$ Clare Hall,

8 University of Cambridge, Herschel Road, Cambridge CB3 9AL, UK; ${ }^{\mathrm{c} D e p a r t m e n t ~ o f ~ N a t u r a l ~}$

9 Sciences, National Museum Wales, Cathays Park, Cardiff CF10 3NP, UK

14 CONTACT Kevin J. Edwards $₫$ kevin.edwards@abdn.ac.uk

15 Tel: $+44(0) 1224272346$

17 Heather Pardoe Email: Heather.Pardoe@museumwales.ac.uk

18 Tel: $+44(0) 2920573294$

19

20

21

22

2310,516 words including references, captions, footnotes 


\begin{abstract}
24 ABSTRACT
25 From its 'modern' pollen-analytical beginnings, the science of what we now term palynology

26 wrestled with terminology and sought an acceptable name for the discipline. Starting in 1943,

27 the mimeographed Pollen Analysis Circular, edited from Ohio by Paul Sears, led to

28 discussion of the content, organisation and naming of a developing discipline. This came to a

29 head in 1944 with Ernst Antev's plea for 'The Right Word' and the suggestion of the word

30 palynology from the Cardiff duo of Harold Hyde and David Williams. In the search for a

31 suitable term, Hyde consulted Cardiff-based Irish classicist Leopold Richardson who advised

32 against the word palynology and suggested six alternatives. Hyde, however, was wedded to

33 the term palynology and, in the interests of euphony and 'hankering after my own offspring',

34 was seemingly able to overcome Richardson's scholarly objections by argument. Hyde and

35 Williams defined palynology as 'the study of pollen and other spores and their dispersal, and

36 applications thereof.' This was considered an advance because alternative terms such as

37 pollen analysis, pollen statistics and pollen science did not include the application or

38 interpretation of pollen evidence. The term palynology quickly found acceptability within the

39 pages of the Pollen Analysis Circular and subsequently received an airing in Nature. Once

40 palynology was adopted by the influential Swede Gunnar Erdtman, it was rapidly accepted by

41 the palaeoecological community.

43 Keywords

44 Palynology; etymology; E.V. Antevs; H.A. Hyde; D.A. Williams; L.J.D. Richardson;

45 G. Erdtman

46

47

48 


\section{1. Introduction}

50 When Lennart von Post presented the first demonstration of quantitative pollen analysis at the

51 Sixteenth Scandinavian Meeting of Natural Scientists in Oslo, July 1916, together with the

52 presentation of pollen diagrams, he termed his study 'pollen analysis' (Swedish:

53 pollenanalysen) (von Post 1916, 1918). As might be said, the rest is history, and the

54 centenary of von Post's lecture has passed with due celebration (e.g. Birks et al. 2016; Birks

55 \& Berglund in press; De Klerk 2017; Edwards 2017; Edwards et al. 2017; Richards 2017).

By the outbreak of World War II in 1939, pollen-analytical studies were embracing

57 microscopic entities other than pollen (and spores) and the international scientific community

58 was also receptive to initiatives to facilitate communication and the exchange of information

59 and to reflect recent developments in the nascent science. This combination of factors led to

60 the coining of the word 'palynology' by Harold Hyde and David Williams (1944) to express

61 more meaningfully the essence and scope of study of pollen analysts. The birth of this

62 neologism was somewhat more complex than might be thought from subsequent

63 commentaries (e.g. Terasmae 1970; Boyd and Hall 1998; Hesse et al. 2009). In particular,

64 archival evidence reveals that the successful word was proposed in the face of scholarly

65 resistance from a forgotten player in this narrative - Leopold Richardson, the third man of

66 palynology. This paper seeks to unravel aspects of the biography of the word and its

67 advocates.

69 2. The Pollen Analysis Circular and the organization of the discipline

70 On 5 May 1943, Paul Bigelow Sears (1891-1990; Figure 1), then Professor of Botany at

71 Oberlin College, Ohio (and later to become Chair of Yale's Conservation Program), issued

72 the first of what were to become eight issues of the Pollen Analysis Circular (1943-1944;

73 Figure 2), succeeded by ten issues of the Pollen and Spore Circular (1945-1954) (Anderson 
74 2006). These mimeographed documents were envisaged as a means 'of a freer interchange of

75 information among those who are interested in pollen analysis in this country', given the

76 'suspension of many scientific meetings and increasing handicaps to travel' (Sears 1943, p.

77 1). Prospective contributors were 'cordially invited to submit brief notes and correspondence,

78 indicating questions on which you would desire information' (ibid.). The launch of the

79 Circular reflected the 'greatly increasing interest in the New World in pollen analytical work'

80 (Verdoorn 1943, p. x), set against the backdrop of censorship and restrictions on the

81 movement of printed matter.

The first seven issues of the Circular contained a diet of news regarding such topics

as expressions of interest in the project, techniques, pollen slide exchanges, sites being

studied, wartime constraints, publications and members' addresses. The issue of the

organization of the discipline is also addressed overtly from issue 3, dated 15 September

1943. Thus, Harvard geomorphologist Kirk Bryan ${ }^{1}$ (1888-1950; Figure 1) suggested the

87 formation of a 'Society for Pollen Analysis' (Bryan 1943, p. 2) and Leonard Richard ('Doc')

88 Wilson ${ }^{2}$ (1906-1998; Figure 1) of the Department of Geology at Coe College, Iowa said there

89 were too many organizations, but he 'would like to see one more that would deal primarily

90 with pollen and spore problems' (Wilson 1943, p. 2). This was echoed in the following

91 Circular by François Émile Matthes ${ }^{3}$ (1874-1948), a Dutch-born geologist of the US

\footnotetext{
${ }^{1}$ Bryan had four children, one of whom is the acclaimed Quaternary palynologist Margaret Bryan Davis.

${ }^{2}$ Wilson was a pioneer palaeopalynologist who had spent a junior year abroad at the University of Leeds in northern England as a botany/geology student from the University of Wisconsin-Madison. At Leeds he was hosted by William Holmes Burrell (1864-1945; Edwards 2017), a bryologist and honorary curator of the herbarium. Burrell (1924) who had been carrying out work on Pennine peats along with others and had been influenced by a visit to Leeds by Gunnar Erdtman (section 5). There were several reasons for Wilson's decision to go to Leeds. His parents thought he should study in England and his student house-mate at Wisconsin was an exchange student from Leeds (Kosanke \& Cross 1995). The student was a grandson of Joseph B. Priestley (1733-1804), dissenting clergyman, Liberal political theorist, scholar and chemist who was credited with the discovery of oxygen. Burrell, along with Sears, had assisted in the $\mathrm{PhD}$ supervision of Wilson after his return to the USA (Wilson 1938). In 1974 Wilson became the $6^{\text {th }}$ recipient of the Gunnar Erdtman International Gold Medal for Palynology.

${ }^{3}$ Matthes was a founder and president of the Association of American Geographers and he introduced the terms nivation and Little Ice Age (Matthes 1939).
} 
92 Geological Survey, while Circular No. 6 (issued on 15 March 1944) contained a note by

93 Ernest [sic.] Antevs who wished 'to endorse Professor Kirk Bryan's suggestion to form a

94 society for pollen science with modest dues and I hope you [Paul Sears] will take the

95 initiative' (Antevs 1944a, p.4). A subsequent letter from William ('Buck') Albert Dreyer of

96 the Department of Zoology at the University of Cincinnati and Secretary of the Ecological

97 Society of America was to similarly entreat Sears for 'a program of some kind on pollen

98 analysis and bog problems...Will you or a colleague... assume responsibility and proceed

99 with the organization at once?' (Dreyer 1944, p. 1). University of Michigan-Ann Arbor

100 palaeobotanist Chester Arthur Arnold (1901-1977) expressed the hope that the

101 “"paleopollenists" and paleobotanists can arrange some sort of program at the forthcoming

102 AAAS [American Association for the Advancement of Science] meeting....We need

103 something of the sort to keep us from getting into a rut' (Arnold 1944, p. 1).

104 Issue 6, however, had also featured an item which was to set in train a fresh identity

105 for the discipline.

106

107 3. The Right Word

108 Ernst Valdemar Antevs (1888-1974; Figure 1), 'Small in stature but large in ability' (Smiley

109 1974, p. 1), was a Swedish national who had received his $\mathrm{PhD}$ from the University of

110 Stockholm where he had studied with the varve chronologist Gerard de Geer. In 1929 he was

111 a contender for de Geer's position as Professor of Geology, but the Chair was awarded to

112 Lennart von Post (Nordlund 2017). From the 1920s onwards he carried out chronological,

113 glacial, climatic and archaeological research in North America (Smiley 1974; Haynes 1990),

114 becoming a US citizen in 1939, he eventually settled in Globe, Arizona from where he

115 submitted the following (Antevs 1944b, pp. 2-3):

116 
THE RIGHT WORD? - Is 'pollen analysis' the proper name for the study of pollen and its applications? The word [sic.] 'pollen analysis' (meaning, I suppose, analysis of peat for pollen) was from the beginning used in Sweden to signify the identification and percentage-determination of the pollen grains of the principal forest trees in peat bogs and lake beds. However, its inadequacy was soon obvious, as shown for instance by Gunnar Erdtman's titles 'Literature on pollen-statistics...' and, beginning in 1932, 'Literature on pollen-statistics and related topics.' Even the combination 'statistical pollen analysis', refers only to the method of getting certain data which in itself has little purpose and which does not apply to or cover all the branches of the pollen studies, much less the application of the direct results to climatic conclusions, etc. It is the knowledge gained from the pollen studies, be these statistical or morphological, or be they concerned with polleninduced diseases as hayfever, etc., that has purpose and significance.

"In this case the international combining form - $\underline{\operatorname{logy}}$ (English spelling) can hardly be used to denote this science, for the name would be, I suppose, 'pollinilogy' (cf. polliniferous, pollinization), which is bad.

"To me 'pollen science’ (Swedish, ‘pollenvetenskap'; German 'Pollenwissenschaft') and 'pollen scientific' sound better. Would 'pollen science' be preferable to 'pollen analysis'?" - Ernst Antevs (Feb. 18, 1944).

Paul Sears's response (p. 3) shows that he was obviously impressed by this:

Both on the grounds of euphony and sense, this suggestion from Dr. Antevs appeals to me. I am inclined to suggest, if it meets with no objection, and if 
142

143

144

145

146

147

148

149

150

151

152

153

154

155

156

157

158

159

160

161

162

163

164

165

166

interest warrants continuing this circular after the present year, that issues beginning in 1945 be entitled "Pollen Science Circular."

Issue no. 7 of the Circular was dated 1 July 1944, and its first page carried a contribution from Anthony Orville Dahl (1910-2003; Figure 1) a plant cyto-taxonomist and aerobiologist probably then at Harvard, although about to return to his doctoral institution of Minnesota-Minneapolis (Abbe 1972; Rowley and Rowley 2003):

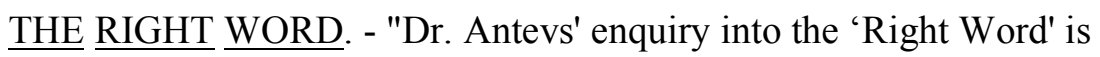
interesting. It appears that we grant awkward phrases an incidental existence without being particularly aware of their ineptness. I have no set feelings on this subject - however, I wonder whether the term 'analysis' hasn't been used, consciously or otherwise, in the sense of 'syllabus' - of knowledge gained from the use of numerous and varied research techniques applicable to the many phases (ecological, atmospheric, morphological, cytological, genetical, etc.) of pollen study. If this is not the usual interpretation, 'pollen science' would seem like a more apt and generalized expression. Some of the difficulty as Dr. Antevs suggests, appears to be initially imposed by the fact that the term 'pollen' is not readily plastic in the manner that, for example, 'cytology' and 'anatomy' are." - A. Orville Dahl (Mar. 31, 1944)

Pollen Analysis Circular No. 8, issued 28 October 1944, contained two items relevant to 'The Right Word'. The second of these was an undated letter from Kirk Bryan (Bryan 1944, p. 6): 
167

168

169

170

171

172

173

174

175

176

177

178

179

180

181

182

183

184

185

186

187

"I have been toying with the idea of 'micro-paleobotany' as including most

of the work on pollen and spores and also all minor constituents of peat

and humus layers of vegetative remains which have to be identified by

microscopic work. We have a micro-paleontology, and this term is now

current. It is not a perfect term, as the interest of the society is in the

paleontology of microscopic animals. Hence micro-paleontology is badly

constructed. Micro-paleobotany would have the same objection. It is also

true that some of these people who are interested in pollen from the

standpoint of human allergies might not take kindly to the name which

implies that the principle [sic.] objectives have to do with past events.

Naturally the geological adherents are primarily interested from the point

of view of the past, and have only nominal interest in methods of detecting

different types of pollen, etc. We, of course, realize that in order for the

paleobotanists' conclusions to be valid, identification must be absolute, but

obviously we cannot retain too much interest in the methods by which

absolute identification is achieved."

Bryan's note had been preceded by what was to become the crucial intervention in the naming of the discipline. It was submitted by an interesting pairing. Harold Augustus $\operatorname{Hyde}^{4}$ (1892-1973; Harrison 1974; Figure 1) was a Cambridge-trained botanist who had become Keeper of Botany in 1922 at the National Museum of Wales in Cardiff. His wide

\footnotetext{
${ }^{4}$ Hyde, son of a hairdresser, was born in Ipswich, Suffolk, England. He graduated with a BA from Downing College, Cambridge in 1914 and then became a schoolmaster in Birmingham and Stamford, Lincolnshire. Five months before the end of the First World War, he joined the British Army's Royal Garrison Artillery as part of the Territorial Force (volunteer reserve) and served in France with the rank of $2^{\text {nd }}$ Lieutenant. From 1919 he was a teacher at Tonbridge School, Kent, before his National Museum of Wales appointment in 1922. He remained in Cardiff for the rest of his life. He married Dorothy Kathleen Smallman (1894-?1985) from Tenbury, Worcestershire in 1917 and they had two children.
} 
botanical interests included Quaternary pollen and aeropalynology as well as flowering plants and ferns (e.g. Hyde and Wade 1934, 1940; Hyde 1940; Hyde and Williams 1945; Hyde and Adams 1958). His association with David Aelwyn Williams ('DA'; 1907-1986; BHD 1986;

Figure 1) began in 1940. 'By chance a physician seeking information on pollen (in the air) to be made in Europe' (Hyde and Williams 1953, p. 84). In 1943 they published their first

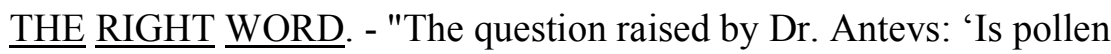
analysis the proper name for the study of pollen and its applications?' and his suggestion to replace it by 'pollen science' interests us very much. We entirely agree that a new term is needed but in view of the fact that pollen analysts normally include in their counts the spores of such plants as ferns and mosses we think that some word carrying a wider connotation than pollen seems to be called for. We would therefore suggest palynology from

\footnotetext{
${ }^{5}$ Williams, the son of a mining engineer, was born in Cardiff, Wales and spent most of his life there apart from clinical training at University College Hospital, London. Marrying Marjorie McVicar (1909-1970) in 1935, he ran the first Asthma and Allergy Clinic in Wales from 1935 onwards (BHD 1986; Thomas 1986). He completed his MD thesis on allergy to milk in 1937. Williams became acquainted with Hyde because he recognised the link between pollen and allergies and sought a botanist with similar interests with whom to conduct research into the subject. With the support of a Cardiff Council grant, Hyde and Williams founded the Asthma and Allergy Research Unit - perhaps the first publicly funded asthma research unit in the UK. His cooperation with Hyde led Williams to study mould spores as a cause of allergies and asthma. Williams rose to become consultant physician to the Cardiff teaching hospitals and he was honoured by British, European and American allergy academies. He was regarded as a fine teacher and clinician, and two of his four children became doctors. He was considered to be an intensely modest, private man, a music lover and a keen angler, 'deeply interested in people and their welfare' (ibid. p. 540).
} 
207 Greek $\pi \alpha \lambda u ́ v \omega$ (paluno), to strew or sprinkle; cf. $\pi \alpha \lambda \eta$ (palé), fine meal;

208 cognate with Latin pollen, flour, dust): the study of pollen and other spores

209 and their dispersal, and applications thereof. We venture to hope that the

210 sequence of consonants p-1-n (suggesting pollen, but with a difference) and

211 the general euphony of the new word may commend it to our fellow

212 workers in this field. We have been assisted in the coining of this new word

213 by Mr. L.J.D. Richardson, M.A., University College, Cardiff." (H.A. Hyde

214 and D.A. Williams, July 15, 1944. Wales).

215

216 4. Archive gold 6

217 Leopold John Dixon Richardson ('Reekie'; 1893-1979; Figure 1) was a gifted scholar,

218 showing a talent for Latin, Greek and Mathematics from an early age. He entered Trinity

219 College Dublin (TCD) in 1912 and went on to accumulate academic prizes ${ }^{8}$ as newspaper

220 entries record the growing list of dead from World War I and Dublin was experiencing the

221 Easter Rising (witnessed by Richardson ${ }^{9}$ ). By 1929, he had been awarded a TCD Fellowship

\footnotetext{
${ }^{6}$ In September 2016, while lecturing at Amgueddfa Cymru National Museum Wales in Cardiff at a Quaternary Research Association conference organised by HSP, KJE discussed the value of archives in studies of the history of palynology. HSP said that an archive of Harold Hyde's correspondence existed in the Museum and invited him to consult it. The opportunity to do so came in December 2016. KJE and HSP sat in the bowels of the Museum and, being aware of the Hyde and Williams suggestion, it made sense to look for any correspondence relating to Richardson. KJE's eyes alighted on a long letter from Richardson and he read it to HSP. She excitedly exclaimed 'That's archive gold!' - hence the title of this section. The authors are undertaking a wider investigation into Hyde (Pardoe \& Edwards, in prep.).

${ }^{7}$ Richardson was born in Rathmines, Dublin, the son of a Protestant drapery warehouseman who hailed from Dungannon, Co. Tyrone in the north of Ireland and a mother from County Louth in the south. Newspaper reports indicate that he was an outstanding student at the High School in Dublin.

${ }^{8}$ At Trinity College Dublin, in the Junior Freshman class, he was placed in the First Rank for Mathematics (Dublin Daily Express 7 May 1913) and a little over a year later he was named one of six Classical Scholars (Belfast News Letter 9 June 1914). He graduated BA in 1916.

${ }^{9}$ In his book Scholars and gypsies: an autobiography, Hispanist Walter Fitzwilliam Starkie, writing of the Easter Rising (Easter Monday, 24 April 1916) when armed Republicans rose up against British rule in Ireland, recorded that his 'friend L.J.D. Richardson or Reekie... had been wandering about most of the day and had
} 
222 (an honour), having previously been 'Lecturer in Greek in Queen's University Belfast, and is

223 at present Lecturer in Latin in University College, Cardiff' (Northern Whig 28 May 1929;

224 Larne Times 1 June 1929). Marrying an equally gifted woman ${ }^{10}$, he rose to become Professor

225 of Greek at Cardiff in 1946 and was Secretary of The Classical Association (1943-1963),

226 which dedicated its $60^{\text {th }}$ society volume to him $(\text { CAP 1963) })^{11}$. His colleague Nick Fisher

227 (pers. comm.) was able to offer some interesting observations:

Richardson retired from the Cardiff Chair in 1958 and returned to Trinity College

Dublin as honorary professor of Greek, although he seems to have retained a house in

witnessed the proclamation of the Sinn Fein Republic at Nelson's Pillar at noon. "It was," he said, "very unimpressive..."' (Starkie 1963, pp. 144-145).

\footnotetext{
${ }^{10}$ Born Frances Petticrew Paton (1895-1955) the daughter of a Protestant clergyman in Ballymena, County Antrim, she accrued numerous prizes from school and university (also Trinity College Dublin) in subjects as diverse as Latin, English, Mathematics, Geography, French and German (graduating with First Class Honours in Modern Languages; Ballymena Observer 27 December 1918) and later a qualification from the Sorbonne, Paris (Ballymena Observer 24 February 1922). Leopold and Frances were married in 1925 and they subsequently had two daughters.

${ }^{11}$ Apart from national involvement, Richardson was also active in the Cardiff branch of the Classical Association, for which he acted as honorary president and he organised many speakers and regular productions of classical plays (Stray 2004).
} 
241 Cardiff $^{12}$. In 1965 he was made both O.B.E. (Order of the British Empire) in the New Year

242 Honours list (London Gazette 1965) and he was elected a Member of the Royal Irish

243 Academy. Frank Mitchell, renowned polymathic Quaternary scientist at Trinity College

244 Dublin, and who figured in a minor way in several issues of the Pollen Analysis Circular,

245 was certainly aware of Richardson. In his autobiographical memoir (Mitchell 1990, p. 56) he

246 observed that the classicist was 'a man of very fertile brain'.

247 Richardson may have become acquainted with Hyde through their involvement with

248 the University where Hyde became an Honorary Lecturer in Economic Botany in 1931-1932.

249 Correspondence between the two dates from February 1934. Richardson's abilities were

250 certainly recognised by Harold Hyde. On 9 June 1944, he wrote (Figure 4; Supplementary

251 Material Figure 2):

252

253

254

255

256

257

Dear Richardson, May I trouble you once again (as I did a few years ago) with one or two matters in which the classical languages impinge on botany?

1. I am very much interested nowadays in the subject of pollen and its dispersal. A subject that has now become so important that one feels the need of a name for it. Please would you give me your opinion on the word palynology? If you approve of it would you be so kind as to tell me exactly how its derivation should be entered in a glossary? (I do not understand the relation between $\pi \alpha \lambda v v \omega \pi \alpha \lambda v v o v$ and $\pi \alpha \lambda \lambda \omega \ldots$... There then follows a query concerning colpi (see electronic copy for full text)]....My interest in these words or proposed words is not purely academic: I want to use them in work to be published and I should be most grateful if you would be so kind as to

\footnotetext{
12 'A passionate collector, Richardson never knowingly threw away any scrap of print, to such an extent in fact that at one time he was reduced to living in the attic of a house otherwise given over to books and newspapers' (Chrimes 1983, p. 225).
} 
give me the benefit of your expert opinion on them. But the matter isn't urgent: if you are full up with exams please don't bother about it for the moment. And if later you would like me to come and see you at the College perhaps you would be so good as to give me a ring?

$\mathrm{H}$

Keeper of the Department of Botany

Two days later, Richardson sent Hyde a postcard (Figure 5):

Very pleased to have these fascinating problems of terminological coinage come my way! Thank you. When the instant pressure of marking

\footnotetext{
${ }^{13}$ This refers to a paper by Leonard Robert Palmer (1906-1984), a classicist at the University of Manchester (later Professor of Comparative Philology at Oxford) in the journal Glotta (a German journal of Greek and Latin historical linguistics, published in Göttingen, not Munich; Palmer 1938, in response to a paper published by Richardson in 1936). Palmer was a controversial figure (The Times 29 August 1984) who worked on material as diverse as the Linear B tablets, archaeological records of Minoan Crete and Chomskian linguistics. With him, 'Sometimes (though rarely) acuteness degenerated into perversity, and enthusiasm into polemics.....and occasionally made things worse by reacting violently.' He began his studies at the then University of South Wales and Monmouthshire and may have met Richardson as a student. During the Second World War he worked on code-breaking and translation for British naval intelligence at Bletchley Park. Richardson once observed that 'classical graduates seem to have a special flair for certain hush-hush work' (Stray 2004, p. 161).
} 
285

286

287

288

289

290

291

292

293

294

295

296

297

298

299

300

301

302

303

304

305

306

307

308

By the end of the following week, he had produced a hand-written, five-page letter

which addressed Hyde's enquiry (Figure 6; Supplementary Material Figure 3). This letter is

a model of erudition and the content relevant to this paper is as follows:

18.vj.' 44

Dear Hyde,

You have given me a very hard nut to crack (now that the

examinations are done with and I have some time for you). The trouble is that, while there is a noun $\pi \alpha \dot{\lambda} \eta \eta$ ['finest meal', 'any very fine dust' e.g. pollen] and

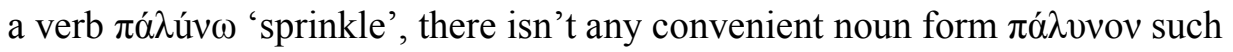
as you quote, so that your palynology would mean 'the science of sprinkling'. The -ology you want should be derived from $\pi \alpha \dot{\alpha} \lambda \eta$. But here there are fresh difficulties. It is not usual to use a Nominative Singular ending in - $\varepsilon$ as a base, but rather to look for an -ŏ- form: geology, geography are exceptions, probably because $v \eta$ is a monosyllable [note that when 'lunar geography' wants a name it becomes selenography not seleneography, from $\sigma \varepsilon \lambda \eta \dot{v \eta] . ~ S o ~ o n ~ t h e s e ~}$ grounds palology ought to be preferred to paleology. But palology is, I think, impossible. It is not significant enough, I mean immediately suggestive of its origin $\pi \alpha \dot{\lambda} \eta$ : and, in any case, one would tend to associate it with $\pi \alpha \dot{\lambda} \mathrm{o \zeta ,}$ taking it to mean 'the science of drawing lots'. We must therefore return to paleology: this would certainly do, only for an unfortunate chance! Namely, that there is already a well established science of palaeology 14 . It would be intolerable to have both paleology and palaeology, sounding the same! Furthermore, if you wanted to name that subsection of your subject in which

${ }^{14}$ The study of antiquities. 
309

310

311

312

313

314

315

316

317

318

319

320

321

322

323

324

325

326

327

328

329

330

331

you are so eminent, viz. the study of the old pollen in bogs (am I right?), you

would be confronted with palaeopaleology (!), on the analogy of

palaeontology.

I can therefore only look around for some other alternatives.

Here are some suggestions for your choice:

(i) Paleology. Correct, but open to the objection outlines above.

(ii) Pollenology. Cuts the knot, but is a flagrant hybrid. Still there are sciences

like mineralogy i.e. mineralology. I don't approve of this, and I don't think you will either.

(iii) Aleurology. This is from another Greek word, ' $\alpha$ $\lambda \varepsilon v \rho o v$ for a fine wheaten flour. 'A $\lambda \varepsilon v \rho o v$ seems to be used to connote a finer flour than ' $\alpha \dot{\lambda} \varphi \iota \tau \alpha$ 'barleygroats', with which it is contrasted for its fineness. But I don't find 'ó $\lambda \varepsilon v \rho o v$ used metaphorically of other dusts, in the way that $\pi \alpha \dot{\lambda} \eta$ is used. Probably a stronger objection would be that that there are (I understand) derivatives already for this word in botany. Isn't there a thing called aleurone? And I remember your Miss Jenkins ${ }^{15}$ identifying a strange fungus which has control of my garage as $\underline{\text { Aleura }}$ $\underline{\text { varia }^{16} \text { ! These (false) associations will probably rule out aleurology. }}$

(iv) Achnology. This is from 'á $\chi v \eta$, 'chaff'. Radically the word seems to mean any light substance that comes off the surface of a solid. Used mostly of chaff that flies off in winnowing, but also of foam, froth, dew, smoke, bloom or down on plums, brass filings, etc.

(v) Lachnology. From $\lambda \alpha \chi^{\prime} \vee \eta$ 'woolly hair', 'down'. Used liked 'á $\chi v \eta$, but this word suggests hairs too much, I think, for your purposes. It is used

\footnotetext{
${ }^{15}$ Miss Eveline Jenkins (1893-1976) was the botanical artist in the Botany Department of the National Museum of Wales between 1927 and 1959; she specialised in fungi (Lazarus and Pardoe 2003).

${ }^{16}$ Aleuria varia (Hedw.) Boud., now known as Peziza varia (Hedw.) Fr.
} 
332

333

334

335

336

337

338

339

340

341

342

343

344

345

346

347

348

349

350

351

352

353

metaphorically of 'the hair of trees' i.e. foliage, like кó $\mu \eta$. Lachnology is not

as good, in my opinion, as achnology.

(vi) Leptology. The science of fine particles, pollen par excellence, from

$\lambda \varepsilon \pi \pi$ ó $\varsigma$ 'fine'. Lepto- is used in a number of scientific terms already.

None of these are/is very satisfactory! So I hazard something else.

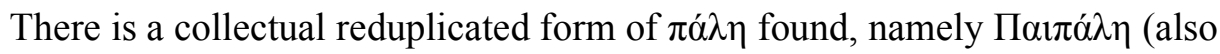

in the form П $\alpha о \pi \alpha ́ \lambda \eta$, once in Aristophanes but otherwise only in the ancient

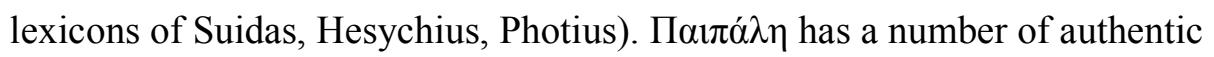

occurrences, as 'first flour', as well as rather more instances of a metaphorical

use $=$ 'subtleties'. Would you stand for paepalology? It sounds rather

forbidding (especially if you are going to be named a palaeopaepalologist!):

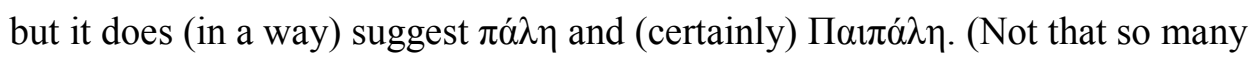

Grecians will know the word!).

I hope I haven’t failed you. Regard these as preliminary suggestions, open to debate, if you would like to discuss them further. I should like to hear your views; and we might be able to hammer out something satisfactory in the end....

I have just bought out of loyalty, etc. - my young friend David Webb's ${ }^{17}$

An Irish Flora (Dundalgan Press, Dundalk). I am not qualified to say anything

about it, except that the glossary of Irish terms for plants looks interesting.

\footnotetext{
${ }^{17}$ David Allardice Webb (1912-1994), noted botanist and eventually Professor of Systematic Botany at Trinity College Dublin. Apart from his Flora and heavy involvement with the Flora Europaea he also produced books on TCD's history and its artwork. He was the 'the eminence grise (and, in later years, eminence blanc) of Irish botany.... a colossus with one foot firmly placed in his native country but the other planted in Britain and Europe... his amazing memory and his working knowledge of some 15 European languages made him both a major driving force and frankly, a somewhat feared figure....the most incisive mind of his generation in College' (TCD 2017). Webb died in a car accident while en route to the herbarium at the University of Reading.
} 
354

355

356

357

358

359

360

361

362

363

364

365

366

367

368

369

370

371

372

373

374

375

376

377
Yours sincerely,

L.J.D. Richardson.

Four days later, a dejected Hyde replied (Figure 7; Supplementary Material Figure 4):

22 June 1944

Dear Richardson,

Very many thanks for your postcard and for your very kind letter.

Evidently I could not possibly have consulted a more enthusiastic philologist

than yourself. I am very grateful indeed for all the thought and trouble you

have devoted to my problem.

Of course I am very disappointed about palynology: I had hoped it

might be acceptable. I had in fact in my ignorance assumed that $\pi \alpha \lambda_{\lambda v v o v}$

(quoted from the Lexicon) was a noun form corresponding with a Latin supine

and meaning 'that which is sprinkled' or something of the kind. I gather that if

I had been right in this respect palynology would have been satisfactory. As it

is I suppose the twist of meaning from 'the science of sprinkling' to 'the

science of that which is sprinkled' would be too great? As I think I explained

in my first letter, I want a word which conveys not only pollen in the strict

botanical sense meaning the male spores of flowering plants but also other

similar material such as the spores of ferns and mosses (these bodies being

commonly included in pollen analyses and their dispersal - by the wind at

least - following the same laws as that of pollen proper).

I must admit that the possible alternatives do not appeal to me so much. 
378 1. Paleology would bear the same relation to palaeology as pedology does to

379 paedology. And is open, as you point out, to a similar objection: there is no

380 need to invent homophones.

3812 2. Pollenology I had of course considered only to condemn it.

382 3. Aleurology would hardly do, because as you say, 'á $\lambda \varepsilon v \rho o v$ has already

383 given rise to the derivative aleurone, meaning the grains of protein found in

384 seeds.

385 4. Achnology and Lachnology seem (may I say it?) to be a little far fetched, 386 especially the latter.

387 5. Leptology : $\lambda \varepsilon \pi \tau$ ó $\varsigma$ has been used by botanists very much in the sense of

388 'thin' rather than 'fine': its botanical derivatives all denote long thin structures.

389

390

And now,

391

392

6. Paepalology. It is obvious even to an illiterate like myself that this is a

393

394

395

396

397

398

399

400

brilliant suggestion but I don't really like it, partly I think because of the

double alliteration and partly because it lacks (to me at least) that

reminiscence of the English word which as the result of the sequence of

consonants, is present in $\mathrm{p}^{*} 1^{*}$ nology.

You see I still have a hankering after my own offspring: is it quite impossible? My new science is to be concerned not only with the material bodies which are strewn but with the processes which bring [it] about and the laws which govern their dispersal (their strewing in fact)....

401

Once again, thank you very much for your most interesting discussion.

402

If I hadn't been a botanist I should have liked to be a philologist. 
403

404

405

406

407

408

409

410

411

412

413

414

415

416

417

418

419

420

421

422

423

424

425

426

427
Thank you too for letting me see your article in the Philosophical

Society's transactions. I wish I were sufficiently learned to understand it.

Yours sincerely,

$\mathrm{H}$

The carbon copy of the letter is followed at its end by two lines of script in Pitman shorthand

(Figure 7). A transcription of this is of critical interest to this account: 'This was all drafted

by that rare conversation of this morning. I am very glad you are able to admit my plea in

favour of palynology.'

Seemingly then, Hyde had been able to persuade Richardson of the acceptability of

his favoured word, palynology. His advocacy of the neologism, spurred on by his love for his

'own offspring', was sufficiently cogent for Richardson (perhaps). Hyde, the philologist

manqué, was sufficiently delighted as to record his success in the shorthand appended to his

letter. Who knows what we should make of the fact that this was the last item in the file

containing their correspondence?

\section{Momentum and acceptance}

Any residual doubts held by Classics scholar Leopold Richardson remain hidden to us, while Harold Hyde, along with Williams, made his play to the Circular.

The new term palynology received a positive response and stimulated discussions concerning the development of the new discipline. In late 1944 Hyde sought to promote the term in a ballot for the naming of the prospective pollen and spore organization called for in the pages of the Circular. His preference is to be found in a hand-written scrap of paper in the Hyde correspondence collection held by Amgueddfa Cymru National Museum Wales (Figure

8) sent to Sears with a covering letter dated 2 September 1944: 
428

429

430

431

432

433

434

435

436

437

438

439

440

441

442

443

444

445

446

447

448

449

450
I suggest that the organisation should be an International association and, if the new word meet [sic.] with approval, the I.A. of Palynologists. Meetings should be held to coincide with International Botanical Congress - i.e. it may be listed, quinquennialy. Dues should cover the production of the circular as a printed publication.

I prefer

PALYNOLOGY, on the analogy of Phytopathology.

However, the relevant meeting (Cleveland, from 13 September 1944) reached a stalemate occasioned by Sears himself (Sears 1944b, p.2):

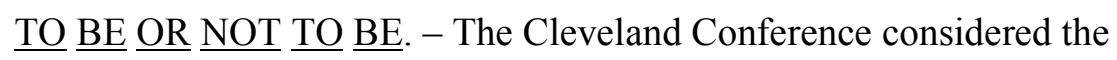
question of organization and decided by a margin of one vote not to organize at this time. The responsible vote was cast - a bit sheepishly - by your editor who confesses to a phobia towards organizations which outlive enthusiasm and justification....

On page 1 of the re-named Pollen and Spore Circular - the $9^{\text {th }}$ issue for the series dated 15 January 1945, Paul Sears said 'We are still intrigued with the suggestion of Professors Hyde and Williams that the term palynology be used to designate the whole science which deals with strewn or scattered organic particles' (Sears 1945a). This was 
451 viewed with some consternation by Hyde (1945a) who responded immediately in a letter to

452 Sears dated 7 March 1945 and published in issue No. 10 of the Circular (15 March 1945; 453 p.5):

$\underline{\text { PALYNOLOGY. - "Thank you for your reference to the word palynology }}$ in Pollen and Spore Circular No. 9 (received today). May I say that Dr. Williams and I did not intend this word to have so wide an application as you have given it. We defined it as 'the study of pollen and other plant spores and their dispersal and application thereof' and intended it to cover the same ground as does the expression 'pollen analysis' as used by Erdtman.

"We cannot however object on logical grounds to the inclusion of fungus and bacterial spores: they obviously fell within the definition (unless, as some writers have suggested, both fungi and bacteria should be excluded from the plant kingdom). But we would certainly not wish to take in e.g. virus particles or dead organic dusts." - H.A. Hyde (Mar. 7, 1945)

472 1944; titled 'Pollen analysis and the museums'), Hyde had already 'jumped the gun' by

473 recording in an asterisked footnote that 'In view of the admitted inadequacy of the expression 474 pollen analysis it has recently been proposed to substitute for it the new word palynology' 475 he does not say that he and Williams had done the proposing! At the end of the article he 
476 states that 'it is quite fitting that fundamental pollen research should be carried on (pending

477 the establishment of an institute of palynology?) in the national museums at least' (p. 149).

478 In the same month that Hyde's rejoinder to Sears appeared in the Circular, Hyde

479 published the definition of the new term, together with a preamble, in the 'News and Views'

480 section of Nature ${ }^{18}$ for 3 March 1945 under the heading 'Studies on pollen analysis'

481 (Anonymous 1945a). The entry makes no mention of Richardson. In the 21 April 1945

482 edition of Nature, and again in the 'News and Views' section, Hyde, it might be presumed,

483 produced an item (Anonymous 1945b) called 'Pollen analysis and the museums' in which we

484 are told that 'H.A. Hyde... has published an informative article on the technique, history and

485 applications of pollen analysis' (p. 489); the topic of museums research and an 'institute of

486 palynology' is reiterated. He then reproduced the first Nature item on page 2 of issue 11 of

487 the Circular which was distributed after 15 December 1945 (Hyde 1945b).

488 In the meantime, Hyde had written a letter to Erdtman (Figure 1) on 1 June 1945

489 (Figure 9) pushing 'palynology': 'I hope you saw our suggestions re 'palynology' in Pollen

490 Analysis Circular Dec. 1944. It was repeated in Nature 3 March 1945.' Erdtman certainly

491 had. He marked the relevant item in his copy of the Circular (Figure 3) with the annotation

492 'Ob! $\rightarrow$ ' ('Ob' probably standing for observe [or Swedish observera] - Erdtman often

493 commented on documents using the language of the original), while the diagonal stripes

494 painted in water colours on the reverse side of the pages are consistent with his artistic

495 activities (Edlund and Winthrop 2014). Furthermore, he produced a paper for Ymer, the

496 journal of the Swedish Society for Anthropology and Geography which would seem to be the

497 first article to refer to palynology in its title, albeit in Swedish - 'Palynologisk forskning'

498 (Palynological research; Erdtman 1945]). Hyde may have been referring to this when he

\footnotetext{
${ }^{18}$ Hyde had sent a letter on behalf of himself and Williams, with the note to be published, to the editor of Nature on 26 January 1945 (Supplementary Material Figure 8). He was also selling the technique locally. In lecture notes for a presentation on 13 February 1945 to the University College of South Wales Biological Society, Hyde declares 'Palynology is a new science with a great future'.
} 
499 wrote to Harry Godwin, the 'father' of British pollen analysis (Edwards 1986, 2017; West

500 2014; Figure 1), on 5 September 1945, ending his letter 'Erdtman has adopted palynology'.

501 Godwin replied on 3 October 1945 with a rather surly observation - 'Yes, I see that Erdtman

502 has adopted Palynology it is quite a good word, but I'm not sure of the need for it. My guess

503 is that it will stick however' (Figure 10; Supplementary Material Figures 6 and 7). On the

504 first page of the Pollen and Spore Circular for 15 December 1945, we read (Sears 1945b):

505

506

507

508

509

510

511

512

513

514

515

516

517

518

519

520

521

522

523
COMMUNICATION RESTORED. Among the most welcome material received in recent months is G. Erdtman's “Literature on Pollen-Statistics and Related Topics Published 1944," bearing the inscription: "Professor Paul B. Sears with compliments and kind regards. Please insert a line in your next Pollen Analysis Circular that I should be glad to receive reprints on 'Palynology' - this seems to be a very good term!

On 16 June 1946, Erdtman wrote to New Zealand palynologist Lucy May Watson Smith (née Cranwell; 1907-2000; Davis 2017), then resident in Washington D.C.: 'I hope you will remain in contact with me in any questions on "palynology" (the new term for pollen and spore science!)'. That year, a paper by Erdtman (1946), a Dutch thesis (Eshuis 1946) and a Belgian article (Florschütz \& van Oye, E. L., 1946) had the words palynologiska, palynologisch and palynologique respectively in their titles. By 1947, Erdtman had changed the title of his bibliometric series in Geologiska Föreningens $i$ Stockholm Förhandlingar to 'Literature on palynology'. Apart from this, the first use of the word in the title of an English language publication may also be that of Erdtman (1947; 'Do you collect pollen? The reasons why others gather and study it given in a survey of the newly named science of palynology') in the Journal of the New York Botanical Garden. 
524

525

526

527

528

529

530

531

532

533

534

535

536

537

538

539

540

541

542

543

544

545

546

547

In 1947, Helmut Gams (1893-1976) of the University of Vienna, at the start of his

paper 'Wesen und Stand der Palynologie' (Nature and standing of palynology), quotes the

origins of the word as proferred by the 'englischen' (sic.; Englishmen) Hyde \& Williams

(1944). It is interesting to note that a year later, Stanley Adair Cain (1902-1995), then of the

University of Michigan, also thought it necessary to provide a potted history of the word

palynology in a footnote to a paper in Science, drawing comfort perhaps from the fact that

Erdtman 'has accepted the term' (Cain 1948, p. 115). In his paper 'Palynology. Aspects and

prospects', Erdtman (1948, p. 467) felt able to claim that 'This term [palynology] was

unanimously accepted by the workers in this science and will likely contribute towards a

more common interest in its wide domains'. Godwin seems not to have used the term before

1951 and he may only have ever used the word twice in the title of a paper (Godwin 1951,

1967). It may be that he was somewhat envious of Hyde and Williams' introduction of the

word given his acerbic response to Hyde's letter as noted above.

Hyde remained protective of his term, and when, as late as 1956, Bergen botanist

Knut Fægri (1909-2001; Figure 1) said that "The term "palynology” was coined by Hyde and

Williams to cover all work with pollen grains and spores' (Fægri 1956, p. 639 ${ }^{19}$ ), Hyde put

pen to paper (letter dated 13 March 1957):

Dear Fægri,

Thank you for the two offprints you sent me recently. I am no

polemicist and I am not spoiling for a fight but I must point out that your

assessment of the meaning of the word palynology is inadequate in that you

ignore the words "and their dispersal" included in my original definition.

This definition was expressly framed so as to include the collection and

${ }^{19}$ Fægri also cited the year of publication in the Circular as 1943 rather than 1944. 
548

549

550

551

552

553

554

555

556

557

558

559

560

561

562

563

564

565

566

567

568

569

570

571

572
Dear Hyde,

You are completely right, and I am sorry for the omissions. Queer, though, I am preparing a paper on "aeropalynology” myself!

Sincerely yours

Knut Fægri

Strangely, no editions of the seminal Textbook of (Modern) Pollen Analysis by Fægri and Iversen $(1950,1989)$ discuss or much use the word palynology - indeed, the only index entry in the $4^{\text {th }}$ edition $(1989)$ - 'Palynology (definition) 7 ' - results in a disappointing search on the said page; it appears twice on page 6 , with neither instance being related to a definition!

Hyde remained proprietorial even in later years, for example, Hyde (1969, p. 579) began 'The author reasserts his original definition of palynology', later adding 'Palynology was widely defined by the writer....as the study of plant spores and their dispersal and applications thereof.' He went on to state that 'It has tended to become limited rather to the study of pollen grains in relation to stratigraphical - especially quaternary - geology, but the original definition with its wider connotation still stands. The word 'spore' as here understood includes pollen grains, fungus spores and other microscopic plant disseminules such as hyphal fragments.... algal cells....and lichen soredia....but not bacteria.' As shown above, this broadening of the definition was presaged in the letter to Sears dated 7 March 1945. The 
573 Hyde (1969) paper omitted mention of the 1944 Hyde and Williams item, although he does

574 cite the Anonymous (1945) authorship as by Hyde and Williams. Collectively, this might be

575 interpreted cynically as an attempt by Hyde to take full credit for the original definition,

576 and/or he perhaps felt that the Pollen Circular did not count as a publication worthy of

577 citation.

578 In parallel with the foregoing (and reprising earlier discussions in this paper on the

579 structure of the fields contributing to palynology) there were various society contributions.

580 Erdtman organised a Palynological Conference in 1950 at Bromma, Stockholm (Figure 11),

581 associated with the VII International Botanical Congress. In a letter to Godwin dated January

582 1950, Hyde referred to this meeting rather coolly as 'Erdtman's foregathering'. The final

583 Pollen and Spore Circular (No. 18, January 1954 and edited by Leonard Wilson) contained a

584 report on the 'First [U.S.] Palynology Conference' (Yale, June 1953) and spoke of a meeting

585 to establish an International Commission on Palynology under the organizational leadership

586 of Gunnar Erdtman and Madeleine Van Campo (editor of the Paris-based journal Pollen et

587 Spores [produced 1959-1989]). The American Association of Stratigraphic Palynologists

588 (AASP; now AASP - the Palynological Society) was founded in 1967. The International

589 Commission for Palynology (ICP) began in 1977 and became the International Federation of

590 Palynological Societies (IFPS) in 1984 (Demchuk \& Riding 2008; Traverse 2007; Riding et

591 al. 2016).

592 In a letter to Hyde dated 8 December 1954, concerned inter alia with the meeting

593 which had been held in Paris in July 1954, Knut Fægri recorded that 'I have more and more

594 come to the conclusion that the section of palynology was a mistake. Palynology as a

595 technique involves specialists in so many other branches of science that to collect them gives

596 a completely incoherent congregation.' Similar sentiments were to be recorded in a later

597 paper (Fægri 1956), where he also said that the term palynology is 'convenient and has been 
598

599

600

601

602

603

604

605

606

607

608

609

610

611

612

613

614

615

616

617

618

619

620

621

622

widely accepted, but it must not be taken to indicate that palynology should have a status as a science of its own. This it is not...' (p. 639).

In this instance, the zeitgeist would seem to have escaped Fægri. In 1954, Erdtman began the journal Grana Palynologica, edited from his laboratory in Stockholm. In 1970 it saw a name change to Grana with various subtitles (An International Journal of Palynology; A Journal of Palynology and Aerobiology); the Journal of Palynology from Lucknow first appeared in 1965 (this journal eventually absorbed the Palynological Bulletin which had also been overseen from the Palynological Society of India between 1965 and 1970); the Review of Palaeobotany and Palynology began life in 1967 when it was edited from Utrecht; while the journal Palynology was renamed from Geoscience and Man in 1977.

\section{Conclusions}

This has been a story of people, a discipline and its naming - much of it taking place in the midst of a world war. At its core is a dramatis personae of two wise men (three if David Williams is included) - or is it the stubborn botanist versus the purist classicist? Harold Hyde certainly had the vision to move beyond Ernst Antev's desire for a new name and suggestion of 'pollen science' (supported by Paul Sears and Orville Dahl) and to be more prescriptive than was evident in Kirk Bryan's time-constrained proposal of 'micro-paleobotany'. Sears expressed his post-pollen-scientific interest in the word palynology, but arguably it was Erdtman's renown, influence and imprimatur which sealed the bid. Richardson, meanwhile, has been written out of the word's history other than to be acknowledged once in print after his academic objections had been questioned rather than ignored. Perhaps most of us would be grateful that Hyde fought his corner - to be called a palynologist might be thought preferable to answering to palaeopaepalologist, even if we marvel at Richardson's erudition. Once the new word was unleashed, Hyde set out to promote it successfully and its wider 
623 adoption sustained the momentum. Although Hyde does appear to have allowed some

624 evolution of his definition, it is notable how it has diversified and been redefined between

625 different sub-disciplines. The most notable group could be identified as the

626 palaeopalynologists, as exemplified by the scope of this journal ${ }^{20}$, where the Hyde and

627 Williams 'purist' definition has been significantly extended to include a wide range of

628 organic remains.

629

630

631 Acknowledgements

632 For access to archival information, we would like to thank Amgueddfa Cymru National

633 Museum Wales (Hyde papers and correspondence), Nigel Morgan of Cardiff University

634 Library, Maria Asp and the Center for History of Science, Royal Swedish Academy of

635 Sciences and Pia Östensson and the Swedish Museum of Natural History (Erdtman papers),

636 along with those bodies granting permission to use the portrait photographs. We are grateful

637 to Anne Bryan for the photograph of her father (D.A. Williams) and the valuable background

638 information, to Angela Lord for advice on Greek orthography and to Pat Wiltshire for Pitman

639 shorthand interpretation. We are indebted to Richardson's former colleague, Nick Fisher, for

640 drawing the Starkie autobiography to our attention. The Royal Irish Academy, the Classical

641 Association (Claire Davenport) and Trinity College Dublin (Aisling Lockhart) provided

642 additional information on Richardson. We are appreciative of comments from Ed Schofield

\footnotetext{
${ }^{20}$ The Palynology journal webpage speaks of 'covering all aspects of the science of organic microfossils and their modern counterparts.... We accept papers on both pre-Quaternary and Quaternary palynology, and palaeobotany. Articles across the entire range of palynomorph groups and geological ages are welcomed' (http://www.tandfonline.com/action/journalInformation?show=aimsScope\&journalCode=tpal20); while the AASP - Palynological Society website states that 'Palynology is the study of pollen, spores, dinoflagellates, and other microscopic "palynomorphs." (http://palynology.org/what-is-palynology/) and 'Palynomorphs include both plant and animal structures that are microscopic in size.... In the strict sense, palynomorphs are recognized as microscopic structures that are abundant in most sediments and sedimentary rocks, and are resistant to the routine pollen-extraction procedures....In a broader sense, other microfossils sometimes are given "courtesy appointments" as "palynomorphs" even they do not survive routine pollen-extraction procedures.'

(http://palynology.org/palynomorphs/).
} 
1

2

3

4

5

6

7

8

9

10

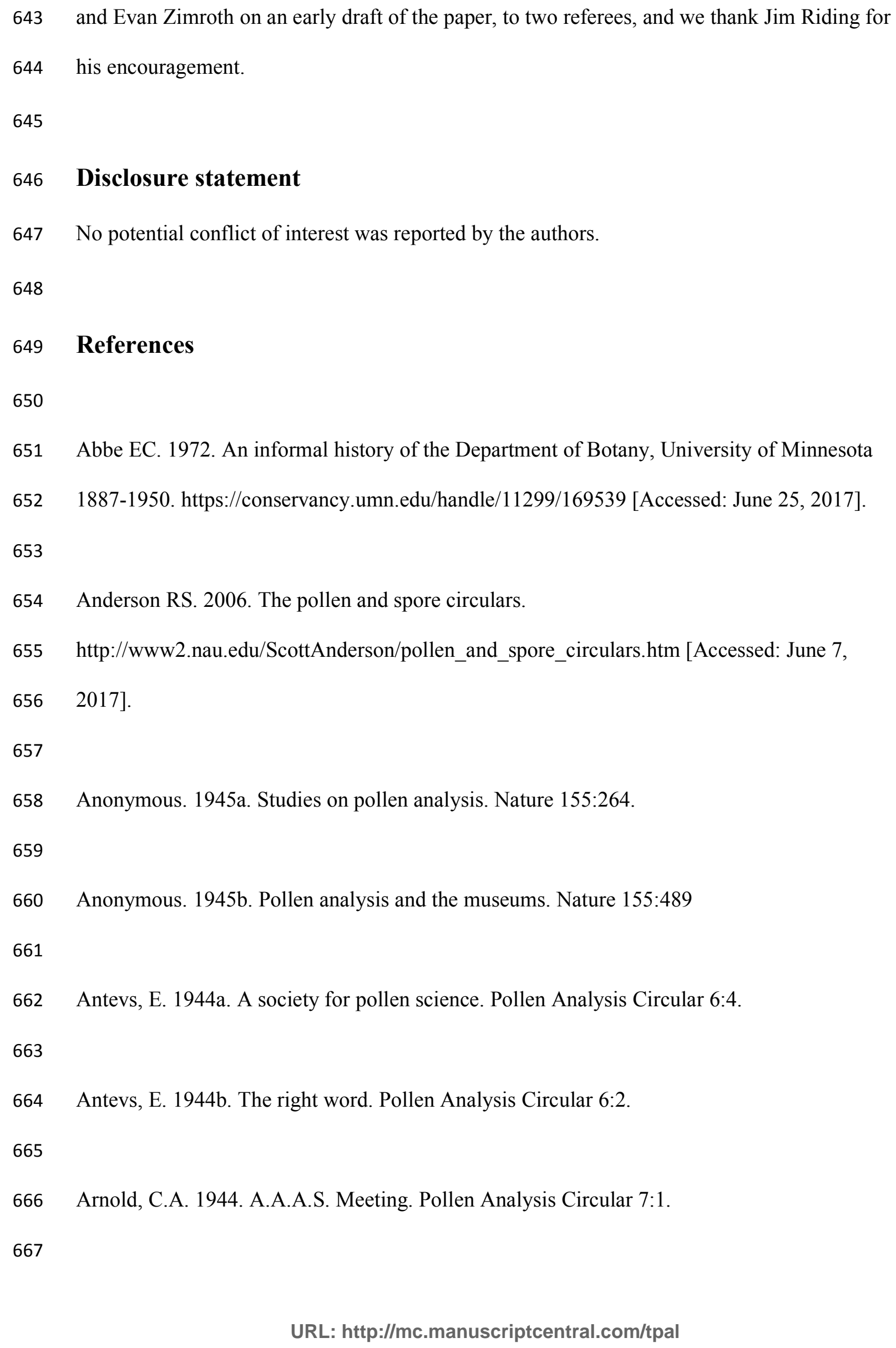


668 BHD. 1986. D A Williams. British Medical Journal 293:60-61.

669

670 Birks HJB, Birks HH, Ammann B. 2016. The fourth dimension of vegetation. Science

$671354: 412-413$.

672

673 Birks HJB, Berglund BE. In press. One hundred years of Quaternary pollen analysis 1916-

674 2016. Vegetation History and Archaeobotany.

675

676 Boyd WE, Hall VA. 1998. Landmarks on the frontiers of palynology: an introduction to the

677 IX International Palynological Congress Special Issue on New Frontiers and Applications in

678 Palynology. Review of Palaeobotany and Palynology 103:1-10.

679

680 Bryan K. 1943. Concerning development of the pollen analysis circular. Pollen Analysis

681 Circular 3:2.

682

683 Bryan K. 1944. No title. Pollen Analysis Circular 8:6.

684

685 Cain SA. 1948. Palynological studies at Sodon Lake: I. Size-frequency study of fossil spruce

686 pollen. Science 108:115-117.

687

688 CAP. 1993. Classical Association Proceedings, volume 60. London: John Murray.

689

690 Chrimes SB., editor. 1983. University College Cardiff A Centenary History 1883-1983.

691 Unpublished manuscript, Cardiff University Library.

692

693 Dahl AO. 1944. The right word. Pollen Analysis Circular 7:1.

694 
695 Davis, O.K. 2017. Lucy May Cranwell Smith 1907-2000.

696 http://www.geo.arizona.edu/palynology/lcrnwobt.html [Accessed: June 23, 2017].

697

698

De Klerk P. 2017. The roots of pollen analysis: the road to Lennart von Post. Vegetation 699 History and Archaeobotany, DOI 10.1007/s00334-017-0626-y.

700

701

702

Demchuk TD, Riding JB. 2008. A history and overview of the American Association of 703

Stratigraphic Palynologists (AASP). Palynology 32:83-100.

704

705

Dreyer WA. 1944. No title. Pollen Analysis Circular 7:1.

706

707

Edlund AF, Winthrop ZA. 2014. Sharing what he saw: an appreciation of Gunnar Erdtman's

708 life and illustrations. Grana 53:1-21

709

710 Edwards KJ. 1986. Professor Sir Harry Godwin F.R.S., 1901-1985, a tribute. Journal of

711 Archaeological Science 13:299-306.

712

713 Edwards KJ. 2017. Pollen, women, war and other things: reflections on the history of

714 palynology. Vegetation History and Archaeobotany, DOI 10.1007/s00334-017-0629-8.

715

716 Edwards KJ, Fyfe RM, Jackson ST. 2017. The first 100 years of pollen analysis. Nature

717 Plants 3, 17001 (2017), DOI: 10.1038/nplants.2017.1

718

719 Erdtman G. 1945. Palynologisk forskning. Ymer 65:130-138.

720 
721 Erdtman G. 1946. Palynologiska synpunkter på pionjärfasen i den svenska florans

722 invandringshistoria. Svensk Botanisk Tidskrift 40: 293-304.

723

724 Erdtman G. 1947. Do you collect pollen? The reasons why others gather and study it given in

725 a survey of the newly named science of palynology. Journal of the New York Botanical

726 Garden 48:245-253.

727

728 Erdtman G. 1948. Palynology. Aspects and prospects. Svensk Botanisk Tidskrift., 42:467729483.

730

731 Erdtman G, Hedberg O, Terasmäe J. 1950. Literature on palynology. XIV. Geologiska

732 Föreningens i Stockholm Förhandlingar 73:99-128.

733

734 Eshuis HJ. 1946. Palynologisch en stratigrafisch onderzoek van de peelvenen. Unpublished

735 PhD Thesis, Rijksuniversiteit Utrecht. 143 pp.

736

737 Fægri K. 1956. Recent trends in palynology. Botanical Review 22:639-664.

738

739 Fægri K, Iversen J. 1950. Text-book of modern pollen analysis. Copenhagen: Ejnar

740 Munksgaard.

741

742 Fægri K, Iversen J. 1989. Texbook of pollen analysis. 4th edition by Fægri K, Kaland PE, 743 Krzywinski K. Chichester: John Wiley \& Sons. 
745 Florschütz F, van Oye EL. 1946. Recherches palynologique dans la région des Hautes Fagnes 746 belges. Biologisch Jaarboek Dodonaea 13:307-315.

747

748 Gams H. 1947. Wesen und stand der Palynologie. Mikroskopie - Zentralblatt für

749 Mikroskopische Forschung und Methodik 2:65-67.

750

751 Godwin H. 1951. Pollen analysis (palynology). Endeavour 10:5-16.

752

753 Godwin H. 1967. The development of Quaternary palynology in the British Isles. Review of

754 Palaeobotany and Palynology 6:9-20.

755

756 Harrison SG. 1974. Harold Augustus Hyde (1892-1973). Watsonia 10:113-114.

757

758 Haynes CV, Jr. 1990. The Antevs-Bryan years and the legacy for Paleoindian geochronology.

759 In: Laporte LF, editor. Establishment of a geologic framework for paleoanthropology.

760 Geological Society of America Special Paper 242. Boulder, Colorado: Geological Society of

761 America; p. 55-68.

762

763 Hesse M, Halbritter H, Zetter R, Weber M, Buchner R, Frosch-Radivo A, Ulrich S. 2009.

764 Pollen terminology. An illustrated handbook. Vienna: Springer.

765

766 Hyde HA. 1940. On a peat bog at Craig-y-llyn, Glam. Data for the study of post-glacial

767 history. IV. New Phytologist 39:226-233.

768

769 Hyde HA. 1944. Pollen analysis and the museums. The Museums Journal 44:145-149. 
770

771 Hyde HA. 1945a. Palynology. Pollen and Spore Circular 10:5.

772

773 Hyde HA. 1945b. Studies on pollen analysis. Pollen and Spore Circular 11:2.

774

775 Hyde HA. 1969. Aeropalynology in Britain - an outline. New Phytologist 68:579-590.

776

777 Hyde HA, Adams KF. 1958. An atlas of airborne pollen grains. London: Macmillan.

778

779 Hyde HA, Wade AE. 1934. Welsh flowering plants: a handbook to the collection in the

780 Welsh National Herbarium. Cardiff: National Museum of Wales and the University of Wales,

781 Cardiff.

782

783 Hyde HA, Wade AE. 1940. Welsh ferns: a descriptive handbook. Second revised edition.

784 Cardiff: National Museum of Wales.

785

786 Hyde HA, Williams, DA. 1943. A census of atmospheric pollen. Nature 151:82-83.

787

788 Hyde HA, Williams DA. 1944. The right word. Pollen Analysis Circular 8:6.

789

790 Hyde HA, Williams DA. 1945. Studies in atmospheric pollen. II. Diurnal variation in the 791 incidence of grass pollen. New Phytologist 44:83-94.

792

793 Hyde HA, Williams DA.1953. The Cardiff Asthma and Allergy Unit and its work. Medical 794 Press 230:83-87. 
795

796 Kosanke RM, Cross AT. 1995. Leonard Richard Wilson (1906-): Palynologist, paleobotanist, 797 and geologist. In: Lyons PC, Morey ED, Wagner RH, editors. Historical perspective of early 798 twentieth century Carboniferous paleobotany in North America. In memory of William Culp 799 Darrah. Geological Society of America Memoir 185. Boulder, Colorado: Geological Society 800 of America; p. 237-244.

801

802 Lazarus MH, Pardoe HS. 2003. Catalogue of Botanical Prints and Drawings at the National 803 Museums \& Galleries of Wales. Cardiff: National Museums \& Galleries of Wales. 804

805 London Gazette. 1965. Supplement to the London Gazette, $1^{\text {st }}$ January 1965:13. 806

807 Matthes FE. 1939. Report of the Committee on Glaciers. Transactions of the American 808 Geophysical Union 1939: 518-523.

809

810 Mitchell F. 1990. The way that I followed: a naturalist's journey around Ireland. Dublin:

811 Country House.

812

813 Nordlund C. 2017. Four Points on Lennart von Post and the Invention of "Pollen Statistics".

814 Vegetation History and Archaeobotany, DOI 10.1007/s00334-017-0628-9.

815

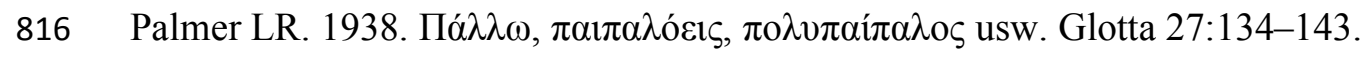
817 
818 Richards K. 2017. Report on the conference to mark the Centenary (1916-2016) of pollen

819 analysis and the legacy of Lennart von Post, Stockholm, November $24-25^{\text {th }} 2016$. AASP -

820 TPS Newsletter 50:21-24.

821

822 Riding JB, Chaloner WG, Farley MB, Rich FJ, Strother PK. 2016. A biography and obituary

823 of Alfred Traverse (1925-2015). Palynology 40:iii-xi.

824

825 Rowley J, Rowley J. 2003. In Memoriam: A. Orville Dahl 1910-2003. Plant Science Bulletin $826 \quad 49: 96$.

827

828 Sears PB. 1943. Foreword. Pollen Analysis Circular 1:1.

829

830 Sears PB. 1944a. No title. Pollen Analysis Circular 6:3.

831

832 Sears PB. 1944b. To be or not to be. Pollen Analysis Circular 8:2.

833

834 Sears PB. 1945a. Change of name. Pollen Analysis Circular 9:1.

835

836 Sears PB. 1945b. Communication restored. Pollen Analysis and Spore Circular 11:1.

837

838 Smiley TL. 1974. Memorial to Ernst Valdemar Antevs. Geological Society of America

839 Memorials 1974:1-7.

840

841 Starkie WF. 1963. Scholars and gypsies: an autobiography, Berkeley and Los Angeles:

842 University of California Press. 
844 Stray C., editor. 2004. The Classical Association: the first century 1903-2003. Oxford:

845 Oxford University Press.

846

847 TCD. 2017. David Allardice Webb (1949-1966). http://www.tcd.ie/Botany/tercentenary/300-

848 years/chairs/david-allardice-webb.php [Accessed 21.06.17]

849

850 Terasmae J. 1970. Quaternary palynology: its scope, problems and potential uses. Geoscience 851 and Man 1:23-27.

852

853 The Times. 1984. Obituary: Prof. Leonard Palmer. The Times 29 August 1984.

854 http://journals.co.za/docserver/fulltext/akro/29/3/432.pdf?expires=1497982705\&id=id\&accna

855 me=guest\&checksum=FA582D2FD5C422C4985AC12BB05FE33E [Accessed: June 20, 856 2017].

857

858 Thomas AJ. 1986. David Aelwyn Williams. Munk’s Roll Volume 8:540.

859

860 Traverse A. 2007. Paleopalynogy. Second edition. Dordrecht: Springer.

861

862 Verdoorn F. 1943. Editor's Preface in Erdtman, G. An introduction to pollen analysis.

863 Watham, Mass: Chronica Botanica Company. 
864

865 West RG. 2014. Quaternary research in Britain and Ireland. A history based on the activities

866 of the Subdepartment of Quaternary Research, University of Cambridge, 1948 - 1994.

867 Leiden: Sidestone Press.

868

869 Wilson, LR. 1938. The postglacial history of vegetation in northwestern Wisconsin. Rhodora $870 \quad 40: 137-175$.

871

872 Wilson LR. 1943. No title. Pollen Analysis Circular 3:2.

873

874 Wilson LR. 1944. No title. Pollen Analysis Circular 7:2.

875

876 Wilson LR. 1954. Pollen and Spore Circular. 18:1-36. 


\section{Figure Captions}

878

879 Figure 1. Pictures of some of the individuals discussed in this paper. Sources: Sears (1944) 880 Oklahoma Hall of Fame; Bryan (c. 1940?) - Savoy Studio, Cambridge, Mass./Geological

Society of America; Wilson (1953) - photographic collection of A.T. Cross/Geological

Society of America; Antevs (c. 1930?) - University of Arizona, Antevs Library; Dahl (c. 1935?) - courtesy of University of Minnesota Archives, University of Minnesota - Twin

Cities; Hyde (1922) - Amgueddfa Cymru National Museum Wales; Williams (c. 1950) Ann Bryan; Richardson (c. 1960?) - The Classical Association; Erdtman (1921) - Jonsell (2007; Svenska Botaniska Föreningen); Godwin (c. 1960?) - F.T.N. Elborn, Department of Plant Sciences, University of Cambridge; Fægri (c. 1960) - Department of Biology, University of Bergen.

Figure 2. The masthead and start of the Pollen Analysis Circular No. 1.

Figure 3. The Hyde \& Williams proposal of the word palynology in the Pollen Analysis Circular No. 8, page 6. The beginning of Kirk Bryan's suggestion of the term micropaleobotany follows. This is taken from Gunnar Erdtman's annotated copy (see text for further details).

Figure 4. Portions of a letter dated 9 June 1944 from Harold Hyde to Leopold Richardson concerning the word palynology (see Supplementary Material Figure 2 for full text).

Figure 5. Postcard dated 11 June 1944 from Leopold Richardson to Harold Hyde stating his willingness to assist linguistic problems of pollen terminology. 
903 Figure 6. Portions of a letter dated 18 June 1944 from Leopold Richardson to Harold Hyde

904 (see Supplementary Material Figure 3 for full text).

905

906 Figure 7. Portions of a 5-page letter dated 22 June 1944 from Harold Hyde to Leopold

907 Richardson and dealing with the coining of the word palynology and various alternatives with

908 Pitman shorthand at the end of the letter (see Supplementary Material Figure 4 for full text).

909

910 Figure 8. Handwritten note from Harold Hyde to Paul Sears concerning the naming of a

911 pollen and spore organization, sent 2 September 1944.

912

913 Figure 9. Letter dated 1 June 1945 from Harold Hyde to Gunnar Erdtman including mention 914 of the word palynology.

916 Figure 10. Fragments of letters between Harold Hyde (dated 5 September 1945) and Harry

917 Godwin (dated 3 October 1945) (see Supplementary Material Figures 6 and 7).

918

919 Figure 11. Members of the 'first international meeting of palynologists, the Conference of

920 Palynology, Stockholm (Bromma) July 1950’ (p.100, Erdtman et al. 1950; published by

921 permission of Geologiska föreningen). Note the following delegates cited in the current

922 paper: Gunnar Erdtman, Harold Hyde, Harry Godwin, Johs. Iversen, Knut Fægri, Frank

923 Mitchell, Orville Dahl.

924 
925 Supplementary Material Figure Captions

926

927 Supplementary Material Figures 1a and 1b. Letter dated 15 July 1944 from Harold Hyde to

928 Paul Sears. The telephone number Llandaff 1078 is that at Leopold Richardson's home.

929

930 Supplementary Material Figures 2a and 2b. Letter dated 9 June 1944 from Harold Hyde to 931 Leopold Richardson.

932

933 Supplementary Material Figures 3a-3e. Letter dated 18 June 1944 from Leopold Richardson 934 to Harold Hyde.

935

936 Supplementary Material Figures 4a and 4b. Letter dated 22 June 1944 from Harold Hyde to 937 Leopold Richardson.

938

939 Supplementary Material Figures 5a and 5b. Letter dated 7 March 1945 from Harold Hyde to 940 Paul Sears.

941

942 Supplementary Material Figures 6a and 6b. Letter dated 5 September 1945 from Harold Hyde 943 to Harry Godwin (dated 3 October 1945).

944

945 Supplementary Material Figures 7a and 7b. Letter dated 3 October 1945 from Harry Godwin 946 to Harold Hyde. 
1

2

3

4

5

6

7

8

9

10

11

12

13

14

15

16

17

18

19

20

21

22

23

24

25

26

27

28

29

30

31

32

33

34

35

36

37

38

39

40

41

42

43

44

45

46

47

48

49

50

51

52

53

54

55

56

57

58

59

60

948 Supplementary Material Figure 8. Covering letter to Nature dated 26 January 1945 from

949 Harold Hyde and David Williams.

950 


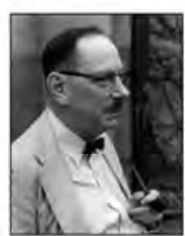

Paul Sears

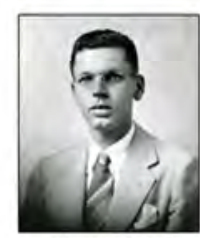

Orville Dahl

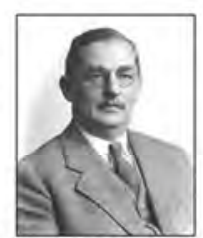

Kirk Bryan

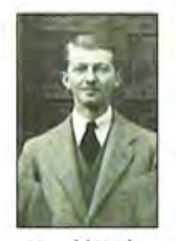

Harold Hyde

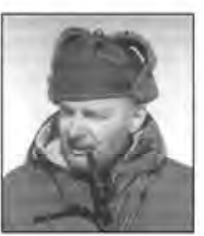

Leonard Wilson

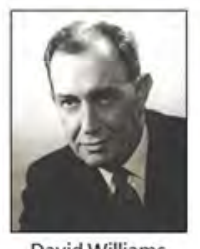

David Williams

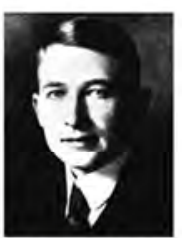

Ernst Antevs

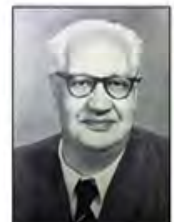

Leopold Richardson

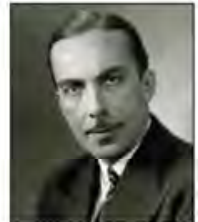

Gunnar Erdtman

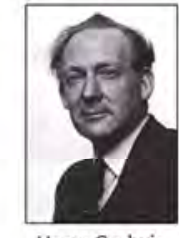

Harry Godwin

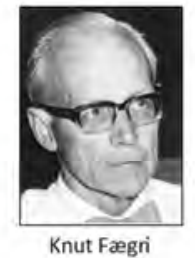

Knut Fægri

Figure 1. Pictures of some of the individuals discussed in this paper. Sources: Sears (1944) - Oklahoma Hall of Fame; Bryan (c. 1940?) - Savoy Studio, Cambridge, Mass./Geological Society of America; Wilson (1953) - photographic collection of A.T. Cross/Geological Society of America; Antevs (c. 1930?) - University of Arizona, Antevs Library; Dahl (c. 1935?) - courtesy of University of Minnesota Archives, University of Minnesota - Twin Cities; Hyde (1922) - Amgueddfa Cymru National Museum Wales; Williams (c. 1950) Ann Bryan; Richardson (c. 1960?) - The Classical Association; Erdtman (1921) - Jonsell (2007; Svenska Botaniska Föreningen); Godwin (c. 1960?) - F.T.N. Elborn, Department of Plant Sciences, University of Cambridge; Fægri (c. 1960) - Department of Biology, University of Bergen.

$$
190 \times 338 \mathrm{~mm}(96 \times 96 \mathrm{DPI})
$$


Figure 2. The masthead and start of the Pollen Analysis Circular No. 1.

$$
377 \times 156 \mathrm{~mm}(120 \times 120 \mathrm{DPI})
$$

FORENORD. Because of the suspension of many goientific meetinge and Increasing handicapg to travel, the undersigned foeln groatly the noed of a froer interchange of inforiastion anons those who ere Interestad in pollen anslysis in this country. He is ther ofore roady to underwrite tho preparation and malling of tuo issues to those who any be intarested, after which, if tho rooponse ocerse to juatify it, Profosoor i. $k$. Hison of coe Collego, Codsr Rapids, Iowa, has indicated that ho will bo willing to lindorwrito two additional eirculars, end Profossor J. 3. Potzgor of autlez University, Indianapolis, Indiana, two voro.

You are thorefor cordially invited to subnit belof notes and correspondenco, indi cating quostions on which you would 10 eira infor antion and giving any information

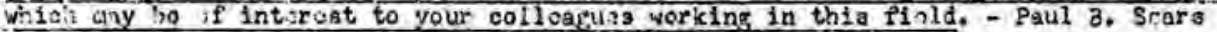


Figure 3. The Hyde \& Williams proposal of the word palynology in the Pollen Analysis Circular No. 8, page 6. The beginning of Kirk Bryan's suggestion of the term micro-paleobotany follows. This is taken from Gunnar Erdtman's annotated copy (see text for further details).

$$
503 \times 282 \mathrm{~mm}(180 \times 180 \mathrm{DPI})
$$


L.J.D. R1chardson Esq., Ir.A.,

My interest in these words or proposed words is not purely academic: I want to use them in work to be published and I should be most greterul $1 \rho$ you would be so kind as to give me the beneflt of jour expert opinion on thom. But the mattor 1sn't urgent: if you are full up with exams please con't bothor about it for the moment. And if later you would like me to cone and see you at the College perhaps you would be so good as to glve. me a ring?

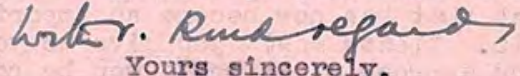

Yours sincerely,

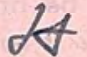

Keeper of the Department of Botany.

Figure 4. Portions of a letter dated 9 June 1944 from Harold Hyde to Leopold Richardson concerning the word palynology (see Supplementary Material Figure 2 for full text).

$232 \times 174 \mathrm{~mm}(150 \times 150 \mathrm{DPI})$ 
Figure 5. Postcard dated 11 June 1944 from Leopold Richardson to Harold Hyde stating his willingness to assist linguistic problems of pollen terminology.

$141 \times 169 \mathrm{~mm}(150 \times 150 \mathrm{DPI})$ 


\section{THE CLASSICAL ASSOCIATION}

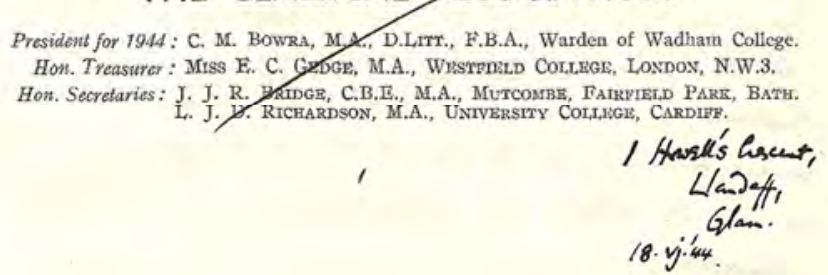

disen His

Figure 6. Portions of a letter dated 18 June 1944 from Leopold Richardson to Harold Hyde (see Supplementary Material Figure 3 for full text).

$$
181 \times 291 \mathrm{~mm}(150 \times 150 \text { DPI })
$$


L.J.D. Rlohardson Esq.,

1 Ilowo L1's Croscont,
Llandaff, Glan.

22 June 1944

Doar stchardson,

Very meny thanks for ycun posteard and for your vory icind letter. viconty I could not possibly hsvo consulted a more enthusiastic ph1lologist than yoursolf. I an very grateful Indeed for all tho biought and troublo you have dovoted to ing groblem.

of course I an very disappointed about palynolost: I had hoped it

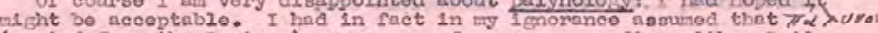
(guoted stom tho Lexicon) wag a noun form corresponding vith a tatin supine and moening that witch 19 sprinkled or sotwotiss

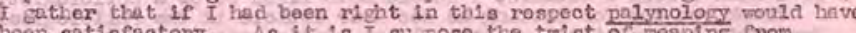

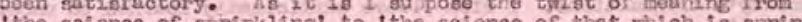
tho be too note sonse nenterin cormoniy Included In pollen analyses and thelr dispergel-by the vind at losse - following the same lava as that of pollon proper). I mist admit that tho possiblo altomatives do not appoal to mo so mioh.

2. Paloology would boar the somo rolation to paleoology as podotosy

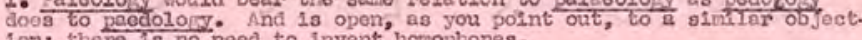
1on: there is no noed to invent homophones.

2. Pollenolosy I had of course consldered only to condern 1 t.

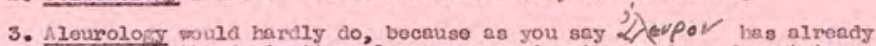

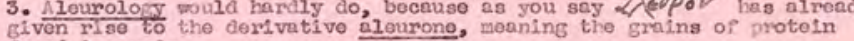
found in seeds.

4. Mahnology and Lachnolory, soen (may I say 1t?) to be a 11 ttlo far

5. Loptology : 入 $\in$ T i's has boon used by botanlsts very wach in fhe

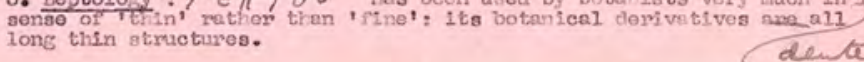

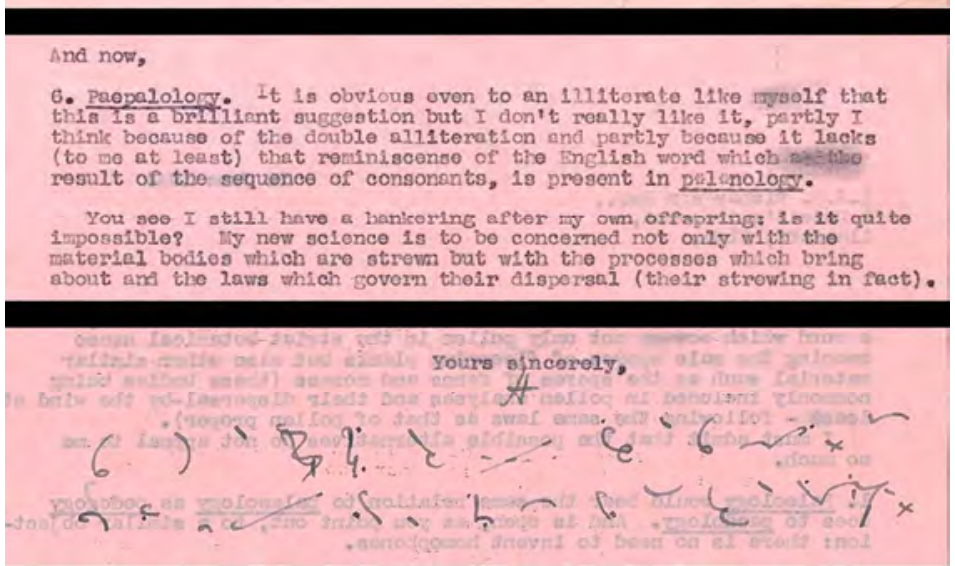

Figure 7. Portions of a 5-page letter dated 22 June 1944 from Harold Hyde to Leopold Richardson and dealing with the coining of the word palynology and various alternatives with Pitman shorthand at the end of the letter (see Supplementary Material Figure 4 for full text).

$173 \times 287 \mathrm{~mm}(150 \times 150 \mathrm{DPI})$ 


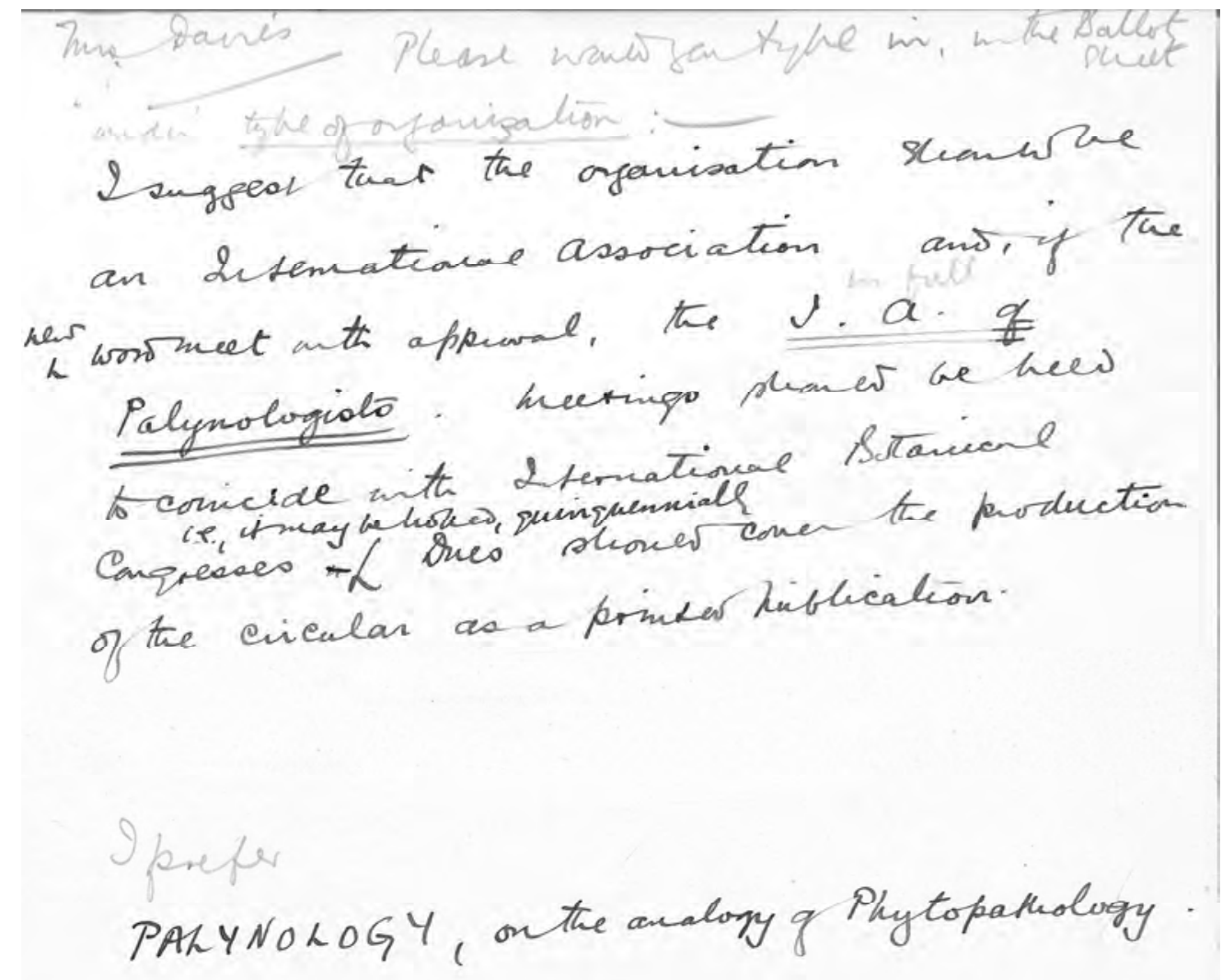

Figure 8. Handwritten note from Harold Hyde to Paul Sears concerning the naming of a pollen and spore organization, sent 2 September 1944.

$168 \times 144 \mathrm{~mm}(300 \times 300$ DPI) 
THL1:PHONF: 3573

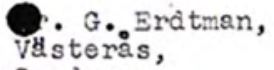
through the British Council. I hope you heve received an offprint of Studies in Atmospheric pollen I. A dally census of pollens at Cardiff 1942 by H.A.H., and D.A. Williams New Phytol. 43.49-61 (1944). I have also published' 'Pollen analysis and the Wuseums' (Wuseums Journal Dec. 1944.). I will try to send you a copy.

Studies II 'Diumal Variation in the Incidence of Grass Pollen' by the same authors is in the press (New Phytol. 44) and I will ask tho pubilshers to send you an offprint.

I hope you saw our suggestion re 'Palynology' in pollen Analysis rroular Dec, 1944. It was repeated in Nature 3 March 1945. We also had a letter on Tilia polien in Nature 14 April 1945.

I find that I now have a complete set of your bibliographles on pollen statistics except for the years 1937, 1938 and 1939 . If you st111 have

offprints of the missing ones and could spare them I should be most grateful.

With all good wishes,

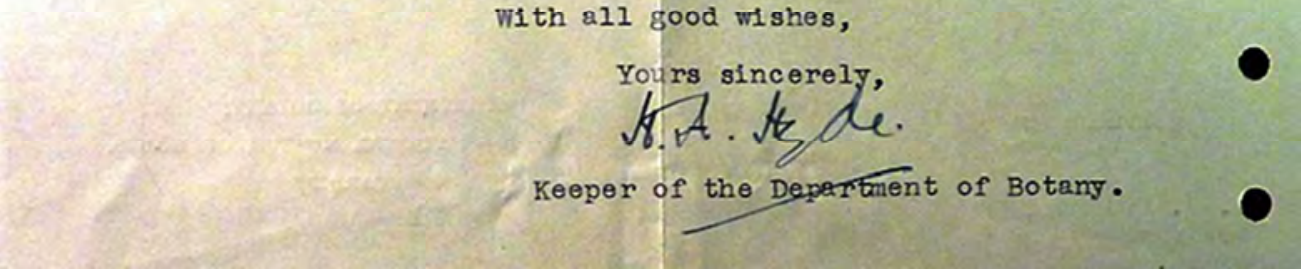

Figure 9. Letter dated 1 June 1945 from Harold Hyde to Gunnar Erdtman including mention of the word palynology.

$177 \times 174 \mathrm{~mm}(96 \times 96$ DPI $)$ 


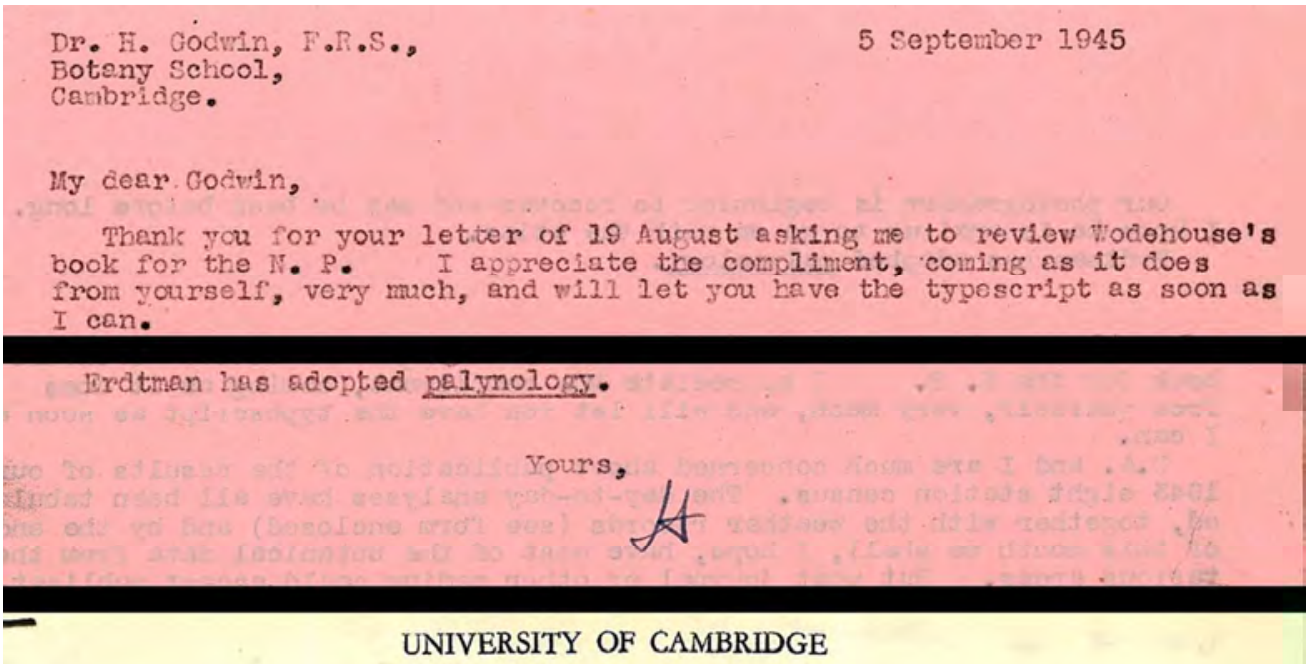

CAMBRIDGE 5113

BOTANY SCHOOL

CAMBRIDGE

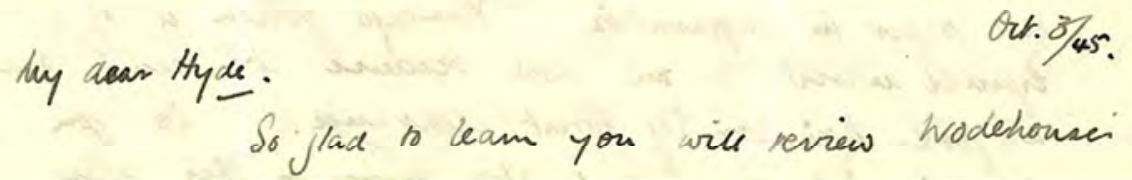

Figure 10. Fragments of letters between Harold Hyde (dated 5 September 1945) and Harry Godwin (dated 3 October 1945) (see Supplementary Material Figures 6 and 7).

$$
183 \times 190 \mathrm{~mm}(150 \times 150 \mathrm{DPI})
$$


Figure 11. Members of the 'first international meeting of palynologists, the Conference of Palynology, Stockholm (Bromma) July 1950' (p.100, Erdtman et al. 1950; published by permission of Geologiska föreningen). Note the following delegates cited in the current paper: Gunnar Erdtman, Harold Hyde, Harry Godwin, Johs. Iversen, Knut Fægri, Frank Mitchell, Orville Dahl.

\section{$123 \times 81 \mathrm{~mm}(300 \times 300 \mathrm{DPI})$}




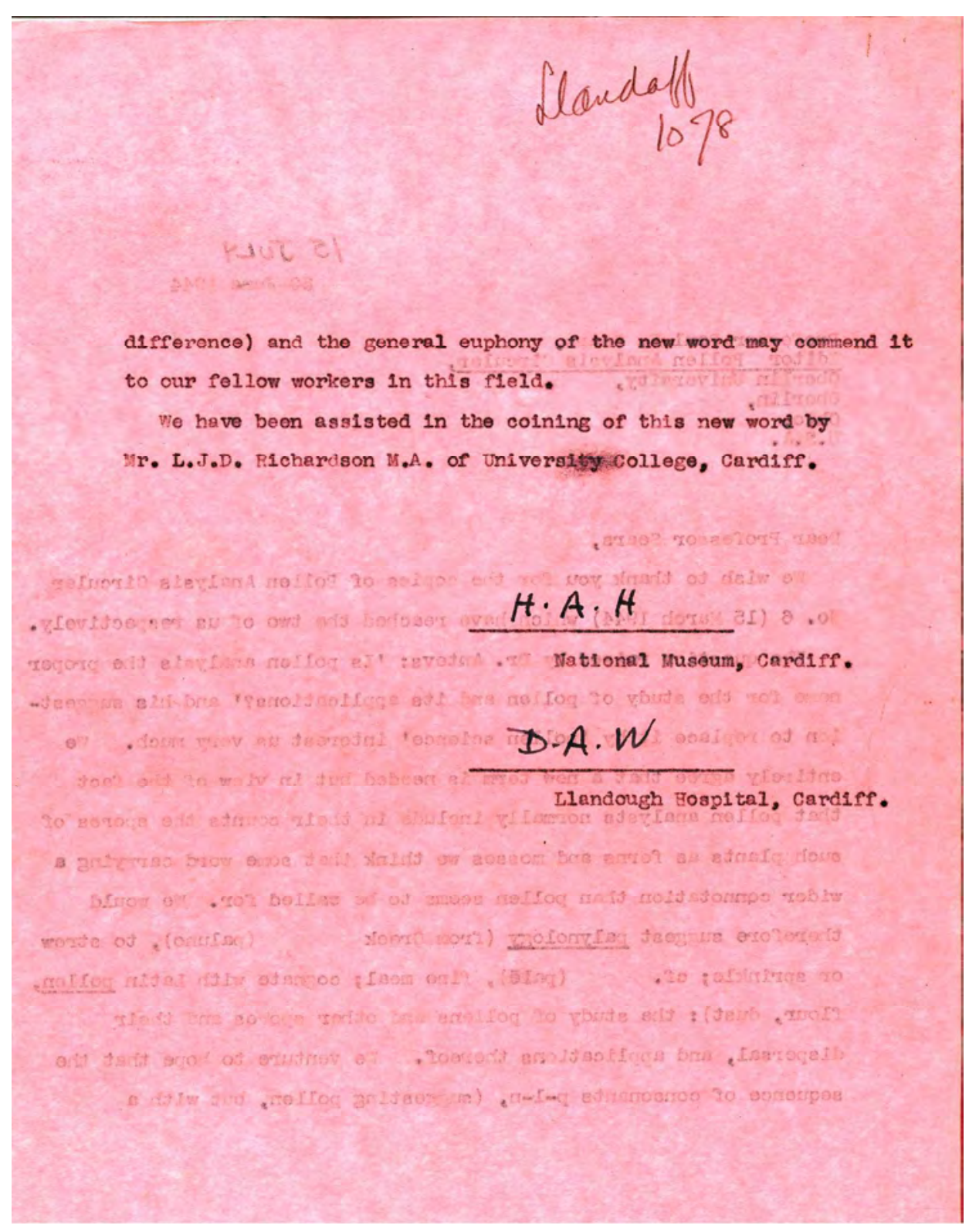

$256 \times 325 \mathrm{~mm}(300 \times 300 \mathrm{DPI})$ 
L.J.D. R1charason Esq., Ir.A.,

9 June 1844

University Colloge,

Cardiff.

Dear R1charison,

Wey I trouble you once again (as I dsd a fow years ago) with one or two matters in which the classlcal languages 1mpinge on boteny? 1. I very much interosted nowndays in the subject of polion ond 1 ts 1. I an dispersal. A subject that has now becowo so lupou me your opinion on the work need of a name for 1t. Please of $1 t$ would you be so kind as to tell mo palynolosy ? If you approve of $1 \mathrm{t}$ would you be so kind as to tell not under. stand the reletion botween $\pi \alpha \lambda \cup V \omega \quad \pi<>v V O V$ and. $\pi \propto>\times \omega$

2. Many kinds of pollen grains are provided with longltudinal grooves or characterised by one author as acolpete, monocolpato, Iurrows and have been characterised by one author as acolpato, monocolpate,

$121 \times 73 \mathrm{~mm}(300 \times 300$ DPI $)$ 
tricolpate according to the number of furrows. These words are tated to hnve boon derlved from the Gk. Ko $>$ tros (a second author has Invented the supposediy Latin homologue colpa, a furrow) and therefore I should heve thought thoy should Instoad he ve been acolple, monocolpic, etc. Du Cange gives a Nedievel Latin form colpus whence I suppose one might have formed noncolpous, unicolpous, eto. Would these guggested alternativos be an improvoment on the orlelnal serlos?

My interest in these words or proposed words is not purely academic: I want to use them in work to be published and I should be most gretervl $1 f$ you would be so kind as to give me the beneflt of your expert opinion on thom. But the mattor 1sn't urgent: if you are full up vith exams please don't bother about 1t for the moment. And if later you would $11 \mathrm{ke}$ me to cone and see you at the College perhaps you would be so good as to g1ve. ne a ring?

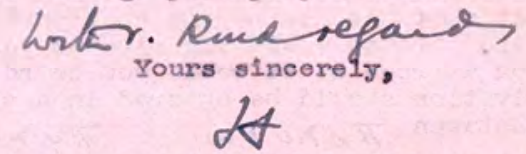

Keeper of the Depertment of Botany. $124 \times 77 \mathrm{~mm}(300 \times 300 \mathrm{DPI})$ 


\section{THE CLASSICAL ASSOCIATION}

President for 1944 : C. M. BowRA, M.D., D.LrTTr., F.B.A., Warden of Wadham College. Hon. Treasurer: Miss E. C. GZDGE, M.A., WeSTHIELD COLLEGE, LONDON, N.W.3.

Hon. Secretaries: J. J. R. DRIDGE, C.B.E., M.A., Mutcombe, FATRFIELD PARK, Bath. L. J. D. RTCHARDSON, M.A., UNIVERSITY COLLEGE, CARDIF,,

$$
\begin{aligned}
& \text { 1 Atwoll's hescent, } \\
& \text { Llandaft, } \\
& \text { Glan. } \\
& \text { 18. vi.utu. }
\end{aligned}
$$

Dean His,

$$
\begin{aligned}
& \text { Yon have wion me a vely hand nut to caeck (kn tant } \\
& \text { ( are lone witk ar I have some time tor que!). The }
\end{aligned}
$$

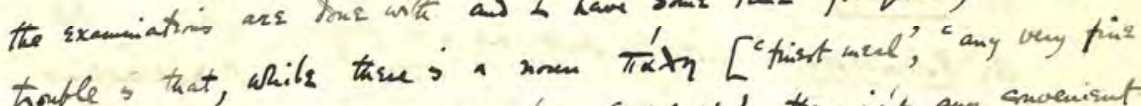
'sprinkls', thise int any snomisut

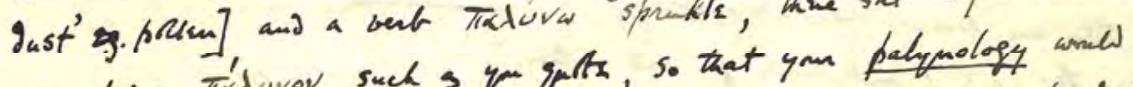

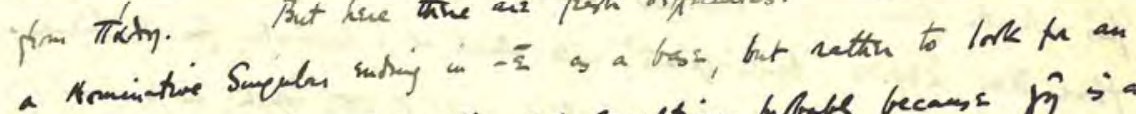

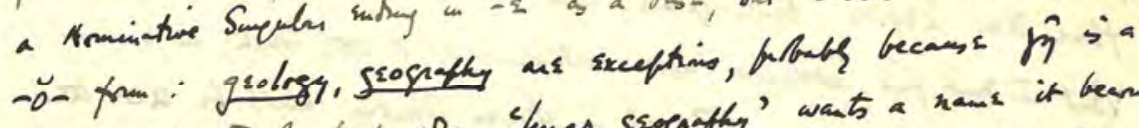

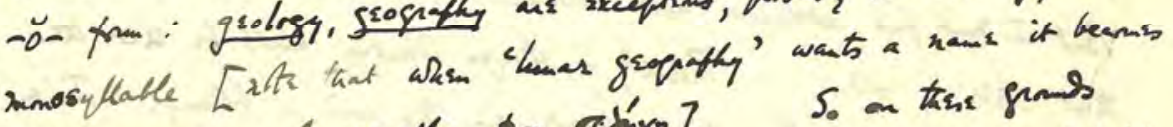

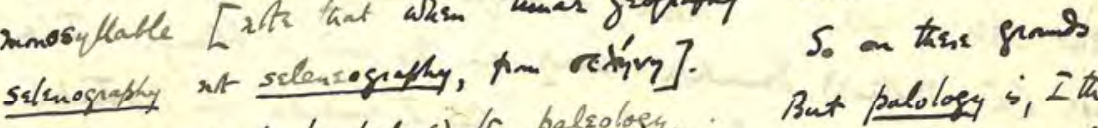

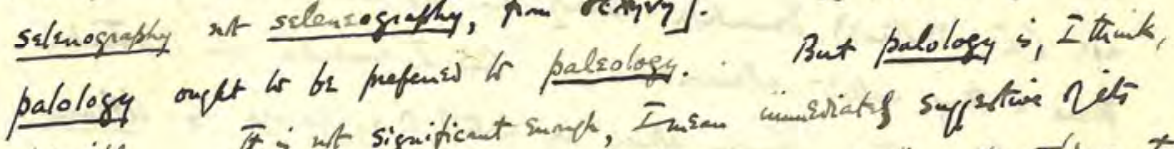

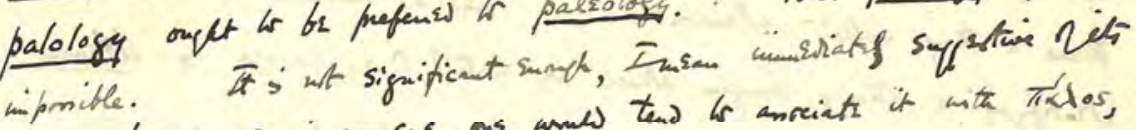

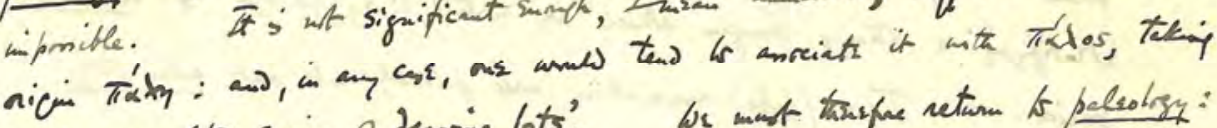

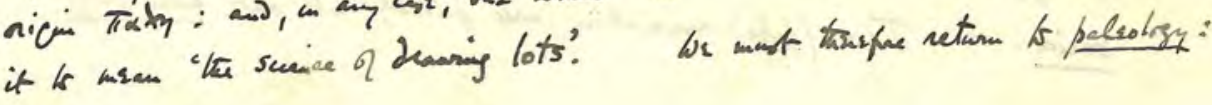




\section{THE CLASSICAL ASSOCIATION}

President for 1944 ; C. M. BowRA, V.A., D.LITT., F.B.A., Warden of Wadham College. Hon. Treasurer: MISS E. C. GEDGE, M.A., WESTFIELD COLLEGE, LONDON, N.W.3. Hon. Secretaries: J. J R. BRIDGe, C.B.E., M.A., Mutcombe, FAIRTIELD PARK, BAth.

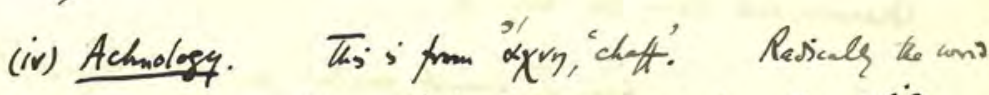

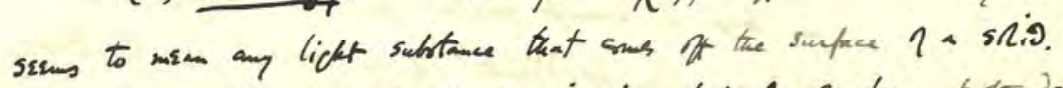

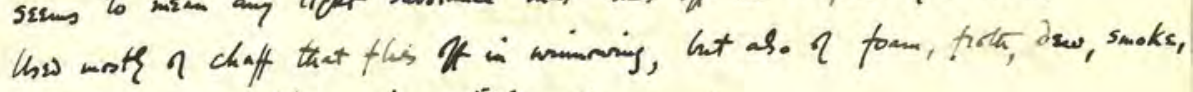

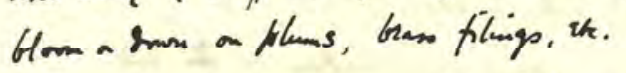

(v) Lachnobogy Ino l'ágry 'woolly hair,' dami. Usal liked

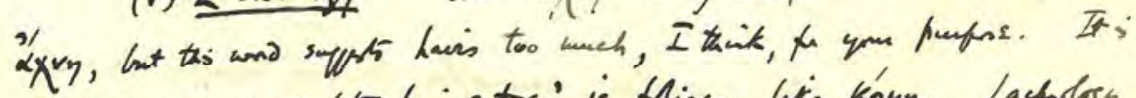

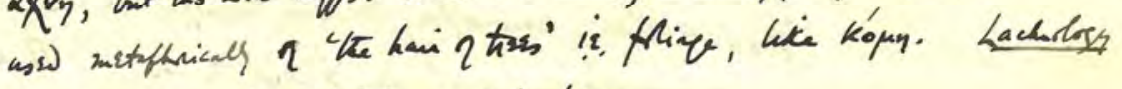
int s fort, in ap pinin, s achnology.

(vi) Lsptology - the scince 1 frici partials, polim par snarlence,

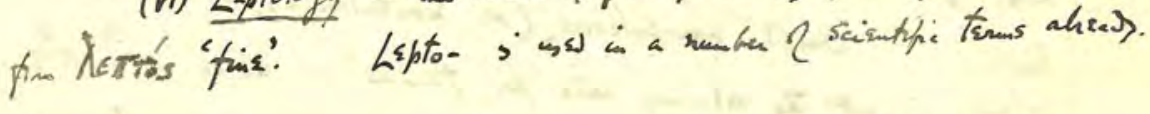

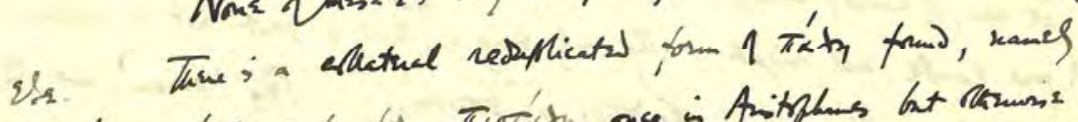

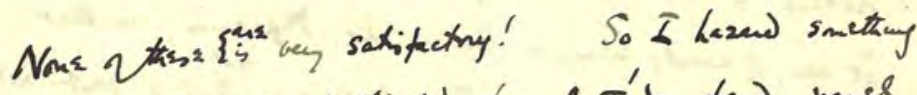

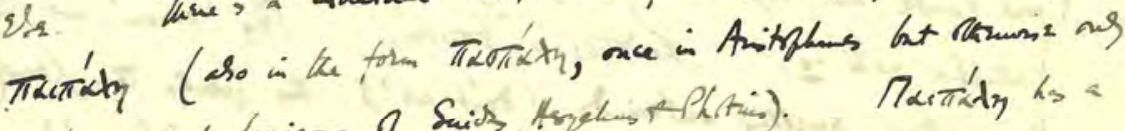

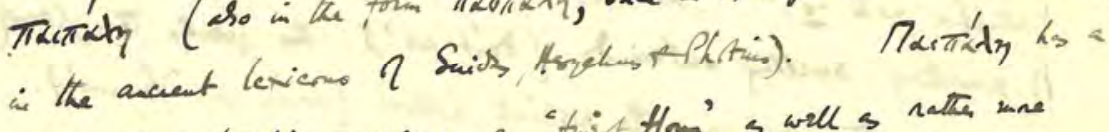

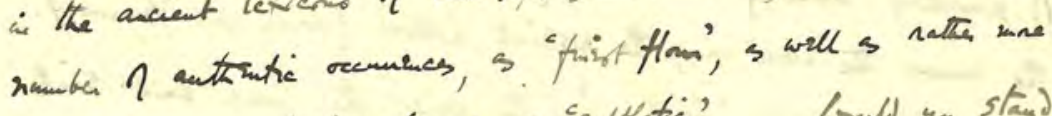

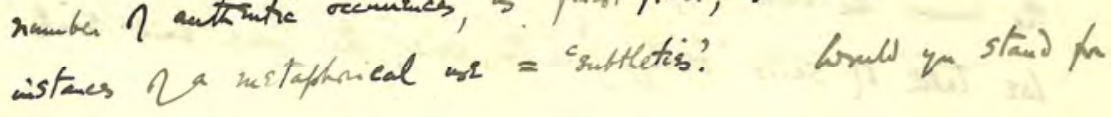

$198 \times 229 \mathrm{~mm}(300 \times 300 \mathrm{DPI})$

URL: http://mc.manuscriptcentral.com/tpal 


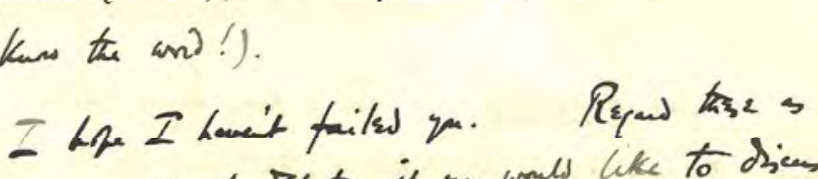

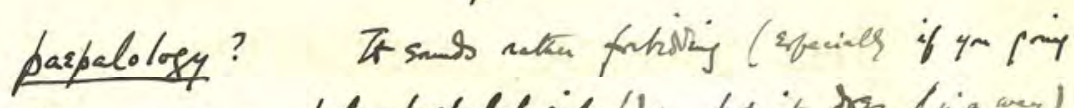
It te numis a pelaespaspalologit!'): hat it biss (ivamey)

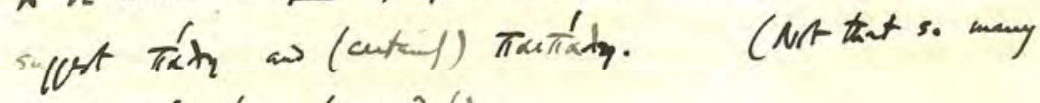

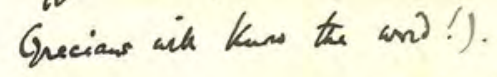

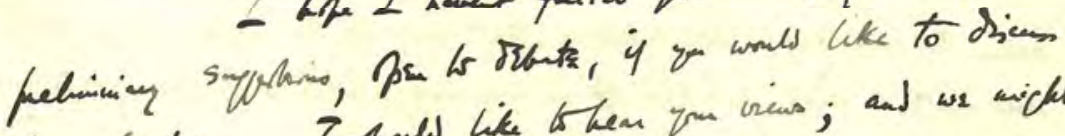

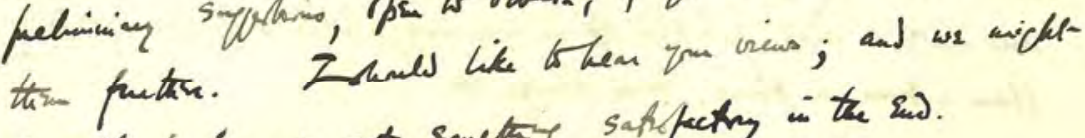

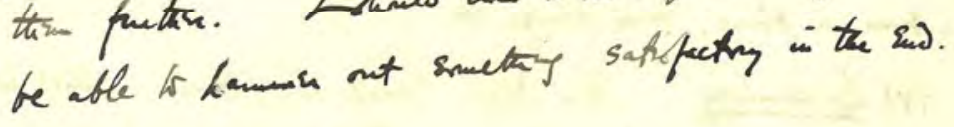

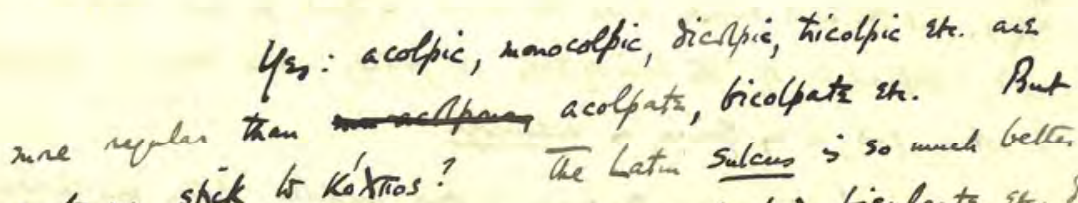

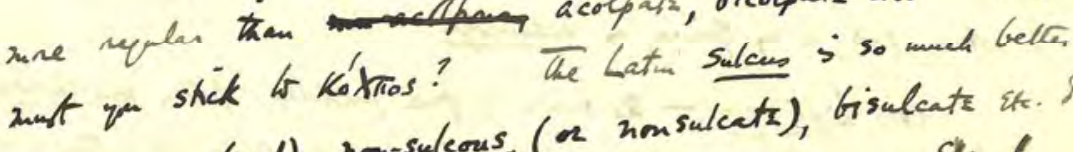

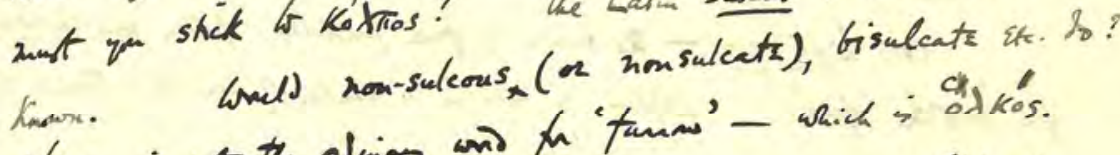

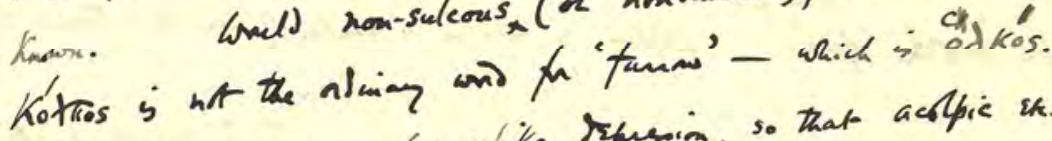

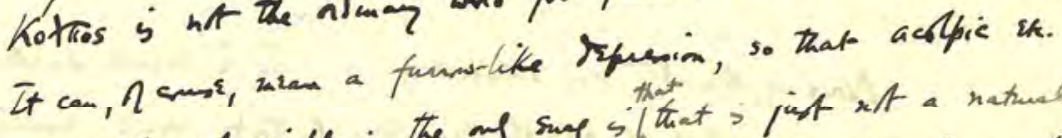

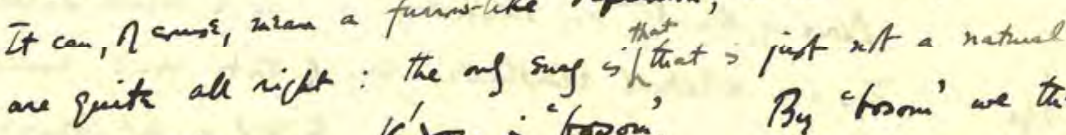

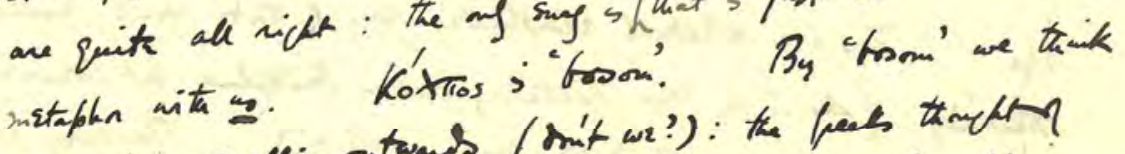

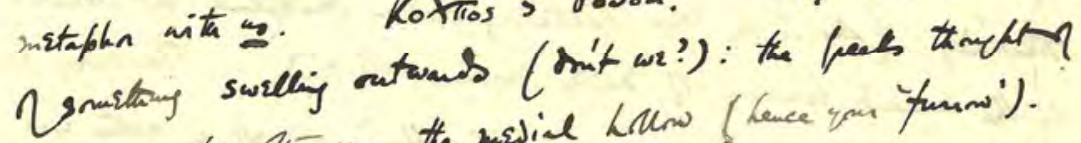

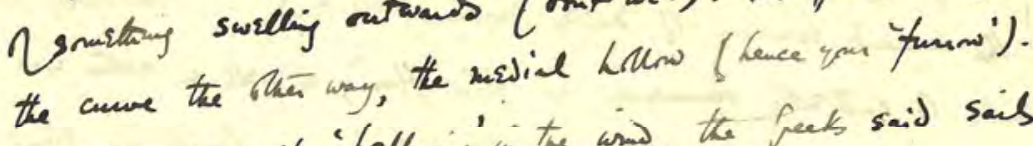

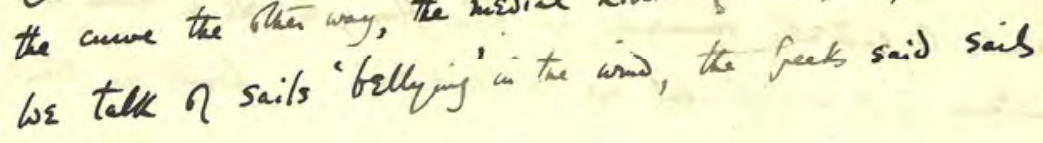
$196 \times 226 \mathrm{~mm}(300 \times 300$ DPI $)$ 


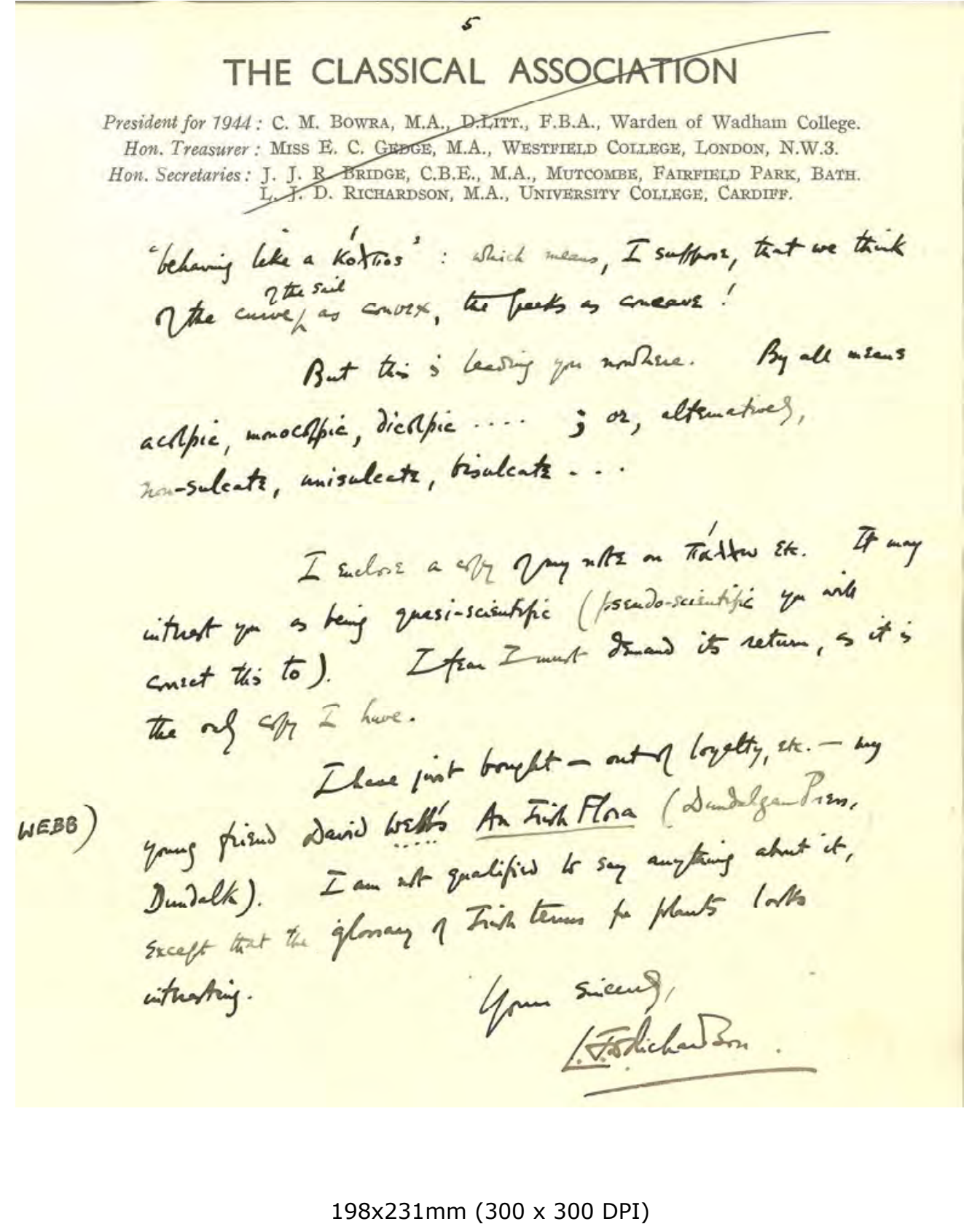

URL: http://mc.manuscriptcentral.com/tpal 
And now,

6. Paepalology. It is obvious even to an 1111terate 11ke mpsolf that

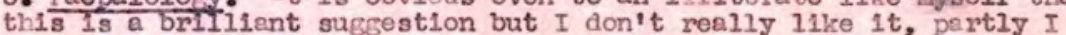
think because of the double all1teration and pertiy because it lacks (to mo at least) that reminiscense of the English word whl ch ad ahe result of the sequence of consonants, is present in pHI nolos:.

You see I st1ll have a hankerlng after ny owm offspring: is $1 t$ quite imposstble? $\mathrm{Hy}$ new sclence is to be concemed not only with the material bodses whlch are strown but with the processes which bring about and the laws which govern thelr dispersal (their strewing in faet).

Thank you for the note on colple and sulcate. The latter is already In existence and $I$ can see no objection to Its being applied to tho grooves in pollen graina. It is a great plty that the American author (R.P. Fodehoue) ever used (o) ToS especlaily sineo lt led hls Swodlsh reliow worker (Eratman) to lnvent colpa, a furrow. Perheps however one ought out of deference todppredecessor to follow hin in using the same root word at the same time correcting the form of 1 ts English derivetives, 1.e. acolple, monocolple ote.

- it onoe again, thank you very much for your most interesting alscussion.

- If to hadn't been a botanlst I should have llked to be a phliologlst.

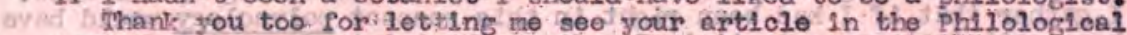
Soclety's trensactions. I vish I were auficientiy learned to underit stand 1 to.

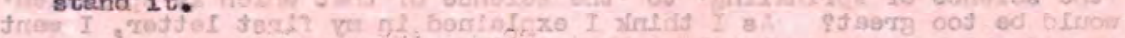

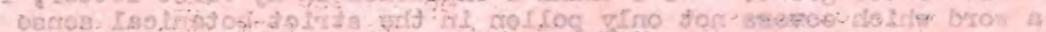

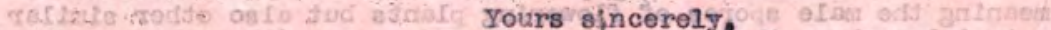

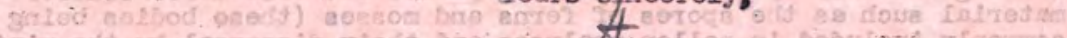

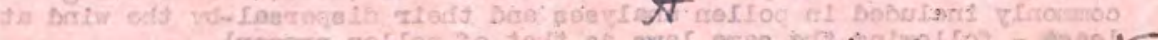

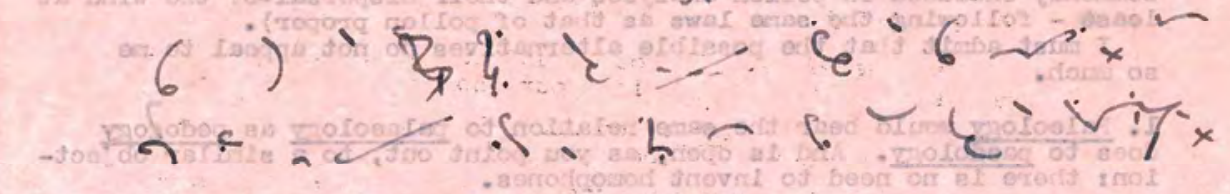

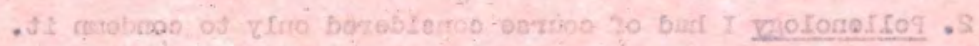

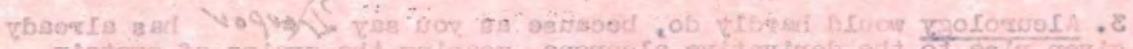

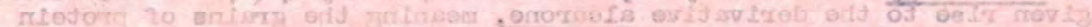
- absos mi betoro?

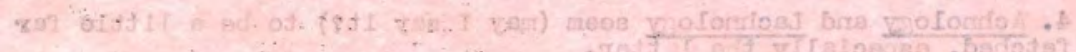

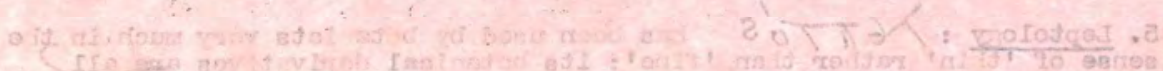

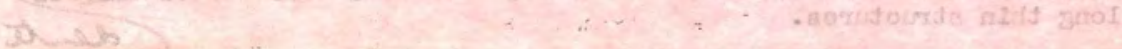
$251 \times 309 \mathrm{~mm}(300 \times 300 \mathrm{DPI})$ 
Profosson reul B. Benrs, Oberlin Colleze, oberlin, Oh1o,

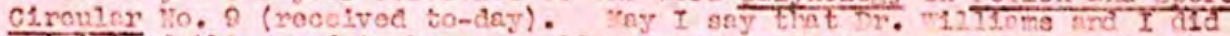
not 1ntond this word to have so vide an application as you havo plvon 1 t. Wo defined it as the etudy of polzen and other plant spores and their diaporsal and applicetiuns thereor' end intonded it to cover tho some fround as does tio exprosnion 'polion enazvets' as used bry Eritumn. We cennot however objoct on $10 \mathrm{~g} 1 \mathrm{cel}$ erounds to the Inelusion of fungus and bicterlal spores: thoy obviousy call within the dorinition (unlosg. as some writers have suscosted, both fungl and bacterla should be oxcluded

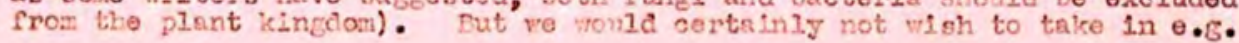

$281 \times 178 \mathrm{~mm}(96 \times 96 \mathrm{DPI})$ 
vimus particles or dead organic dusts.

Yours sincerely,

Keeper of the Department of Botany •

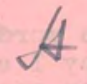

P.S. I am sending uncer separate covor a recent offprint from The Muscums Jouma?.

$125 \times 78 \mathrm{~mm}(300 \times 300 \mathrm{DPI})$ 
Dr. H. Godwin, F.R.S.,
Boteny School,

Cambridge.

My ceer. Gocvin,

Thenk you for your leticer of 19 August asking me to reviev Wociehouse's book for the $H$. P. I appreciate the compliment, coming as $1 t$ does from yourself, vem much, and will let you heve the typoscript as soon as I can.

D.A. and I are mach concemed about publication of the results of our 1943 elght station census. The day-to-day anelyses havo all been tabulated, torether with the weather records (see form onclosed) and by the end of tinls month we shall, I hope, have most of the botanical data from the various ereas. But what journal or other medium could accept publicat1 on of such a mass of stuai? Proc. R.S. (D)? If not, book form seems to be indlceted but of course we would much rather defer that for aome years.

We should heve a Study on dally perlodicity in the incidence of plantain pollen ready by Decerber. 
Our photographer is beginning to recover and may be back before long. I know he is anxicus to go on with the atlas. Erdtman has adopted pelynology.

Yours,

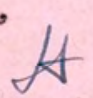

$123 \times 75 \mathrm{~mm}(300 \times 300 \mathrm{DPI})$ 
thy dear thy de.

Or. $3 / 45$.

So jlad to leam you wils review Wodehouse:

book. I was nterested to ser your prelen-cemsus

form: as you suffest is pubrication prisents

bery prow diffimblies, and I tivit any editor would wawt ro know sxactly what is the cane for putrication of the material in toto. $\bar{x}$ seemn to the that you of milliams an the only fork really Whilly to wake ase of the data is thes fomm. Yow wie extrad. frow thens all the genesalisations you can. Ans paper

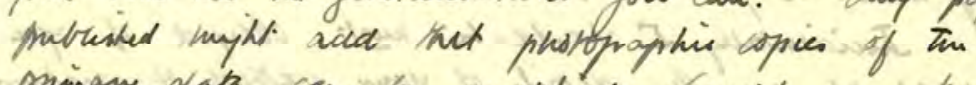
priniary data can oupplied (andfor an kept atio at $x, y+z$ hameing the cetravies or vishsites chosen) IT lile of coase tepresent a worsal effort, it is a matter of assencing ili value in thei ixdenive form. to prebeituen wiel take iv vitiont: sobridy clearly of then only is appendix to a trok, a the way feneticist do.

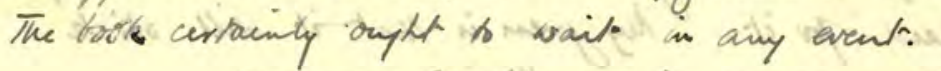
I'm sorm if this advice seem a bit teeck. Whit aboiot a operific frant from a mexical source to $214 \times 228 \mathrm{~mm}(300 \times 300 \mathrm{DPI})$ 
allow an ad hoc publicartion of the tables?

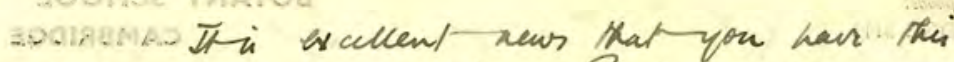
rew paper is mparation. Reawtajo proleen a of especial noternt to me now because it seem such a food indicator of forcht clearance. Do you ever jet Arteniesia which aho tyjires is thes way, or Liguestrum, whic I see Wodechome quoter as a kay. feorer plowt?

I an do pleaned the prospeets for tas poctem attas an inproviciy: I find the reed for is luste corry day. Jult uow a lat. jlaved from the bea talley is engroneny tue rites has a cor of uncuors polen is it. - Incidentally 5 showld be mol oblijed if you. cornld the we the detailh of your method of making co pollen type proparation yrom tiring or hertanim naterial. I don's feel that I know all the tricks I myits about it. Yes, I ser Endtuan his adopha Palynology is is guili a food word, tow Im ure dun of th reed for is. My juen is that it will otick however. 


\section{Page 71 of 71}

Palynology

1

2

3

4

5

6

7

10

11

12

13

14

15

16

17

18

19

20

21

22

23

24

25

26

27

28

29

30

31

32

33

34

35

36

37

38

39

40

41

42

43

44

45

46

47

48

49

50

51

52

53

54

55

56

57

58

59

60

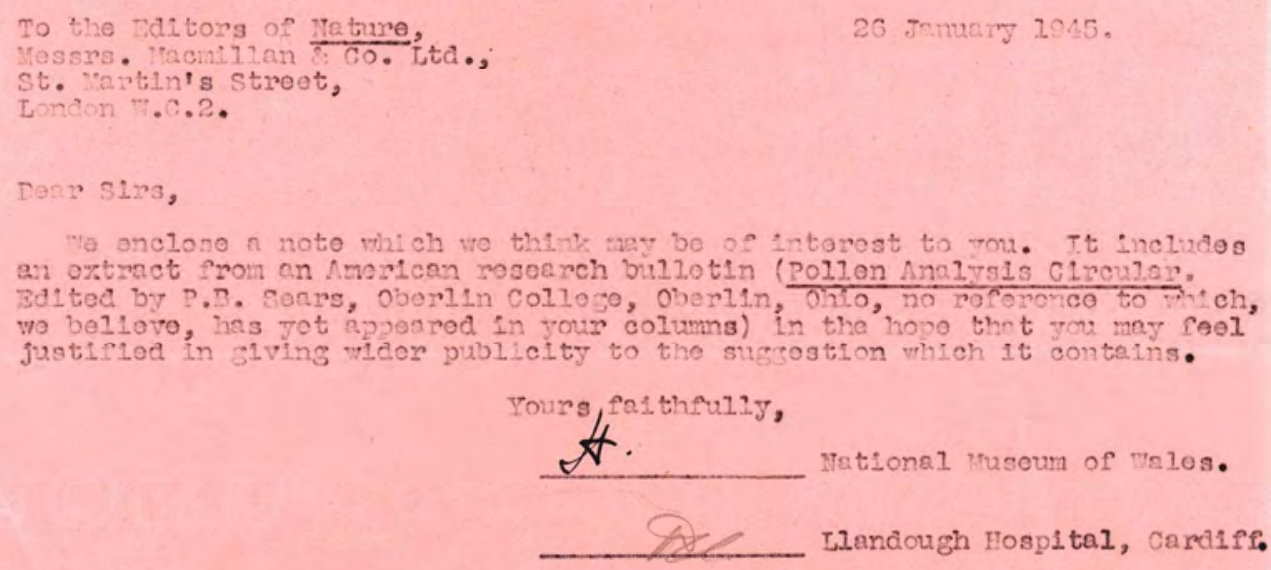

$106 \times 56 \mathrm{~mm}(300 \times 300 \mathrm{DPI})$

URL: http://mc.manuscriptcentral.com/tpal 